\title{
THE LIFE OF TERESA CARREÑO (1853-1917), A VENEZUELAN PRODIGY AND ACCLAIMED ARTIST
}

\author{
By Anna E. KiJas
}

\section{INTRODUCTION AND EARLY MUSICAL YEARS (1853-66)}

María Teresa Gertrudis de Jesús (Carreño) was born on 22 December 1853, in Caracas, Venezuela, to Manuel Antonio Carreño Muñoz (18121874) and Clorinda García de Sena y Rodríguez del Toro (1816-1866). Manuel Antonio was the director of Crédito Público and Ministro de Hacienda in Venezuela, author of the very popular etiquette book Manual de urbanidad y buenas maneras, ${ }^{1}$ amateur musician, and the son of Cayetano Carreño, a Kapellmeister at the Carácas Cathedral. In addition to Teresa, they had three children: María Emilia Gertrudis de Jesús (b. 1841), María Teresa Gertrudis de Jesús (1842-1845), and Manuel Antonio Alejo Ramón del Carmen (b. 1856). Teresa was named after their second child, who had died in November 1845 at the age of three. She began to show musical curiosity and talent at a young age, which led her father to take an interest in developing and nurturing her musical skills, both as a pianist and composer. Carreño's early music education was overseen by her father and, for a short time, German teacher Julio Hohene. ${ }^{2}$ By 1861, Carreño was already composing short works for piano, including eight waltzes, one mazurka, three dances, two polkas, and three capriccios. ${ }^{3}$

During the Federal War (1859-63; also known as the Great War), the family decided to relocate to the United States, where Carreño would

\footnotetext{
Anna E. Kijas is the Head of Lilly Music Library at Tufts University. Her musicological interests include music criticism and reception studies of women musicians in the 19th through early 20th centuries. This biography of Teresa Carreño (1853-1917) is excerpted from the forthcoming book, The Life and Music of Teresa Carreño (1853-1917): A Guide to Research (A-R Editions), which is a survey of extant primary sources, criticism, compositions, and recordings from Carreño's career. Visit annakijas.com to learn more about Kijas's projects and research. Special thanks to Richard Griscom for his editorial assistance on this article as well as the book.

1. Manuel Antonio Carreño, Manual de urbanidad y buenas maneras para uso de la juventud de ambos sexos . . precedidio de un breve tratado sobre los deberes morales del hombre (New York: D. Appleton, 1854).

2. A German piano teacher-cited in sources as Julio Hohene, Julius Hohenus, or in some cases Hoheni-is mentioned in articles discussing her early musical education. See for example Dwight's Journal of Music, 31 January 1863, 350; or La crónica, 12 March 1863.

3. A manuscript of these piano pieces, in her father's hand, is in the Teresa Carreño Papers, series 1, folders 2.9 and 2.13, Vassar College Archives and Special Collections Library. They are included in one modern edition, Theresa Carreño. Obras para piano, eds. Juan Francisco Sans and Laura Pita. Clásicos de la literatura pianística venezolana, vol. 8. (Caracas: Fondo Editorial de Humanidades y Educación, Universidad Central de Venezuela, 2006).
} 
make her public debut as a musical prodigy. The family-including Teresa, her parents, brother, grandmother, uncle and his wife, with their two young children ( 5 and 3 years old), as well as several servantsdeparted onboard the J. P. Maxwell (see fig. 1) from Puerto Caballo, Venezuela, on 23 July 1862, arriving in Philadelphia on 23 August 1862 before settling at 118 2d Avenue in New York City. ${ }^{4}$

Prior to their departure, several articles appeared in Venezuelan newspapers paying tribute to Carreño's musical talents. On 15 July 1862, Jesus Maria Sistiaga wrote in El independiente:

To those who want to read my impressions about the departure of Maria Teresa Carreño. In several days, this eight-year-old prodigy, who from the age of six has been admired and given us the occasion to contemplate her marvelous improvisational ability and musical execution, will depart for New York. ... .

Teresa will receive the baptism of an artist in one of the great capitals of the civilized world: she will make us forget, during the delightful hours she fills with her genius, the horror of the war that devours, like us, our brothers in the North. So much inspiration, what new springs of the future will she not achieve, she who achieves all, impressed with the majesty of the seas and surprising mysterious secrets in the hoarse chords of the winds and the waves $!^{5}$

Other articles, in newspapers such as El independiente, El vigilante, El continental, and El buen sentido, compared Carreño's musical genius with Mozart's, hailed her as a national treasure, and mentioned her plans to travel to the United States and Europe to debut as a pianist.

Unfortunately, the Carreño family's flight from war-torn Venezuela came during the United States' own Civil War (1861-65), which had been underway for a little over a year. Travel on land by railroad or coach was already difficult, but the war made it even more trying and dangerous. At times, it was impossible to cross certain state lines. ${ }^{6}$ Despite these obstacles, Carreño performed along the Eastern Seaboard between 1862 and

4. Passenger Lists of Vessels Arriving at Philadelphia, Pennsylvania: Records of the United States Customs Service, 1745-1997, Records of the Bureau of Customs, record group 36, series M425, roll 85. National Archives, Washington, DC

5. "A los que quieran leer mis impresiones en la partida de Maria Teresa Carreño. Dentro de breves dias partirá para New York ese prodigio de ocho años que á los seis admiraba ya á los que tenian la ocasion de contemplar su portentosa facilidad para la improvisacion y la ejecucion musical: flor preciosa que se abre lozana acariciade porel sol vivificante de los trópicos; ave de hermoso plumaje y de canto dulcísimo que va á derramar en otras regiones los inmensos tesoros de armonía que fecundó en ella la naturaleza de este suelo, tan rico en poesía como en desdichas.-Para ella se escribió-'El cantar no aprendido'-Qué ménos pudiera acordarle en esa hora suprema de sus adioses, yo, amigo de su casa, que estas líneas que darán testimonio á los estranjeros de que en la tierra natal no le faltó sombra amiga ni eco para sus notas divinas?... Teresa va á recibir el bautismo de artista en una de las grandes capitales del mundo civilizado: ella hará olvidar, durante las horas deliciosas que llene con su genio, el horror de la guerra que, como á nosotros, devora á nuestros hermanos del Norte. Cuánta inspiracion, qué nuevas fuentes de porvenir no alcanzará ella que lo alcanza todo, impresionada con la majestad de los mares y sorprendiendo misteriosos secretos en los roncos acordes de los vientos y de las ondas!" Jesus Maria Sistiaga, "Orgullo Nacional," El independiente, 15 July 1862.

6. See Louis M. Gottschalk's first-hand accounts of traveling to performances during the Civil War in S. Frederick Starr, Notes of a Pianist (Princeton, NJ: Princeton University Press, 2006). 


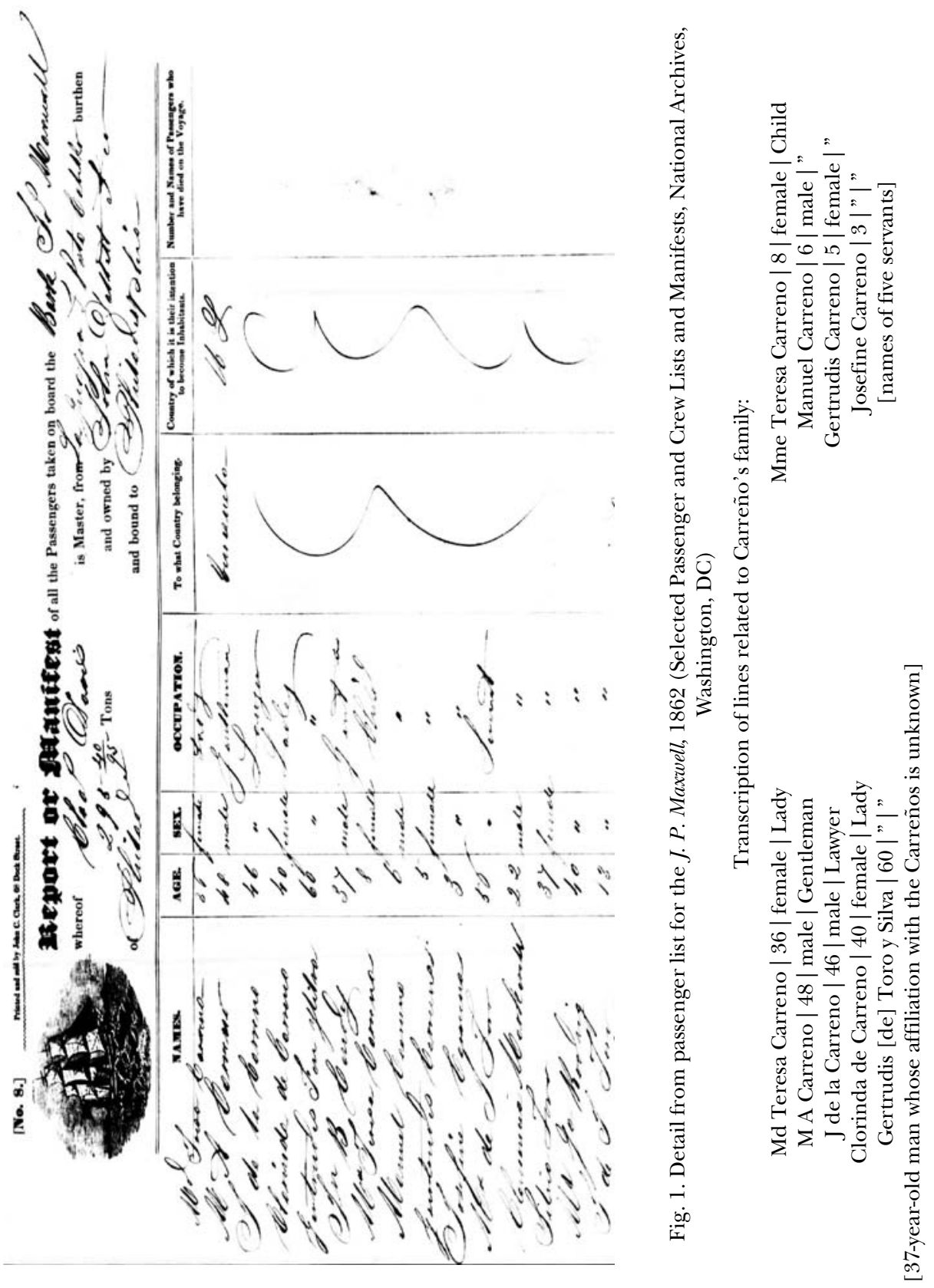


1865 in New York, Massachusetts, Rhode Island, Connecticut, Pennsylvania, Maryland, and the District of Columbia before traveling to Havana, Cuba, and eventually to Paris, France, in 1866. Although New York City was a musical center that had seen its fair share of musical prodigies, several music critics hailed her arrival:

A musical phenomenon has recently arrived in this city whose performances on the pianoforte are exciting quite a sensation. Mlle. Teresa Carreno, the little lady in question, is from Venezuela, and is only eight years old. Her education has hitherto been confined to the care of her father and one or two other amateur musicians. She is a pretty and intelligent little creature, and is in every respect like a child of her age except in her performances. She plays the works of Thalberg, Prudent, Goria and other modern composers with a facility of execution that is truly wonderful. Her reading of the difficult compositions which she plays is entirely her own, she being too young to have ample studies of interpretation. This is in all cases refined, and often original and striking. Her power of [tone?], execution and style of phrasing are such that if one were to hear without seeing her it would be difficult to make him believe that it was the performance of a child. ${ }^{7}$

During her first month in New York City, Carreño was introduced to American pianist and composer Louis Moreau Gottschalk (1829-69), who was thoroughly impressed by her musical abilities and future promise as a concert pianist. Before departing on a tour of the United States and South America, he may have given her some musical instruction. He was eager to promote her to New York impresario Lafayette F. Harrison, writing, "I intend to devote myself to her musical instruction. She must be something great and she shall be." ${ }^{8}$ Indeed, Carreño must have also been awestruck by Gottschalk, dedicating her Gottschalk Waltz (op. 1) to him in 1862.

The US debut of the eight-year-old Carreño took place on 25 November 1862 at Irving Hall in New York City and was followed by approximately eleven concerts in New York City through December 22 (her birthday). At the first concert, she performed Rondo brillant, op. 98, by Johann Nepomuk Hummel (originally for piano and orchestra; for this performance she was accompanied by a string quintet); Grande fantaisie sur "Moise," op. 33, and Variations on "Home! Sweet Home!," op. 72, by Sigismond Thalberg; Nocturne by Theodor Döhler; and Jerusalem by Louis M. Gottschalk. The critic for the New York Times proclaimed, "Miss Teresa Carreño's début, on Tuesday night, more than fulfilled the promise of

7. New York Herald, 27 October 1862.

8. Letter from Gottschalk to Lafayette F. Harrison. Teresa Carreño Papers, folder 11.1, scrapbook 1, May 1862-July 1868. 
her private performances, to which we have before referred. She deserves to be ranked, not as a child-wonder, who at the age of eight years has vanquished nearly all the technical difficulties of the piano, but as an artist of first-class sensibility." "And a critic for La América, a New York Spanish-language newspaper, wrote, "We predict that this is the brilliant destiny that awaits Teresita Carreño in the musical world, we race to include an accompanying biographical note, which we publish with double pleasure in the columns of La América; First because it will be the first newspaper to do so in Spanish, and second, because it will always be the first page in your history of triumphs." 10

On the heels of her New York triumphs, Carreño set off to conquer Boston, debuting on 2 January 1863 at the Boston Music Hall, followed by performances across Massachusetts, Rhode Island, and Connecticut through early February. (See sample program in fig. 2). While the public-and most music critics-received her with great applause and amazement, there were a few who were skeptical of child prodigies and the business of musical enterprise. One of these was John Sullivan Dwight (1813-1893), who reviewed several of Teresa's early concerts in Boston. He made his stance on prodigies clear with statements such as, "Little Miss Teresa Careno [sic] is indeed a wonder. We do not care much for 'prodigies,' but this one did interest us." And warnings: "The danger is lest her talent, by such early continual exhibition and exposure, should all run to waste in superficial, showy music; and no less, that such abnormal and excessive tasking of the brain should wear the life out soon."11 Dwight's proclamation that Carreño would succumb to the fate of musical prodigies and be worn out before she could develop into a competent and talented musician proved to be false, of course, and she would go on to perform for almost fifty-five years.

For performances during her first few years in the United States (186265) and in France (1866), she often performed the works in table 1.

\section{EUROPEAN PERFORMANCES (1866-72)}

Following her American concert debuts, Carreño traveled to Paris, arriving in the first week of May after a treacherous voyage, which required

9. New York Times, 28 November 1862,5 .

10. "Nosotros previendo que eso es el destino brillante que espera á Teresita Carreño en el mundo músical, recogemos á la carrera la adjunta nota biográfica, que publicamos con doble placer en las columnas de La America; lo uno porque será el primer periódico en hacerlo en español, lo otro porque esta siempre será la primera pagína de su historia de triunfos." La América, 17 December 1862.

11. For further information on these early concerts, performance reception, and exploitation of child prodigies, see Anna Kijas, "Teresa Carreño 'Such Gifts Are of God, and Ought Not to Be Prostituted for Mere Gain,' " in Musical Prodigies: Interpretations from Psychology, Music Education, Musicology and Ethnomusicology, ed. Gary McPhersonn (New York: Oxford University Press, 2016), 621-37. See also reviews in Dwight's Journal of Music, 10 January 1863, 327; and 17 January 1863, 335. 
ADIHU TO \#OETOON. TERESA CARRENO'S FAREWEXX GONCERT

\author{
I.AST APPFARA NGE,
}

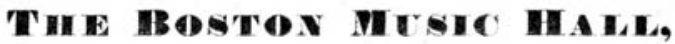

ON FRIDAY EVENING, JANUARY 30th, 1863.

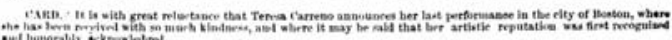

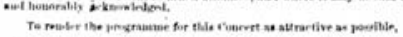

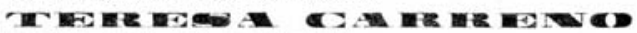

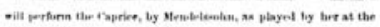

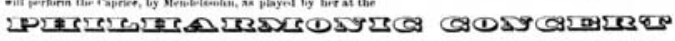

A GOLD MFDAT.

TIIE SONATA PITHETIQUE, BY THE IMMORTAL BEETHOVEN.

THE ORCHESTRA HAS MREN ORGANTZED AND CARL ZERRAHN

nOLOISTS:

Miss ADDIE S. RYAN, Vocalist,

Mr. SUCK, Violinist,

Mr. BAUMBACH, Accompanyist.

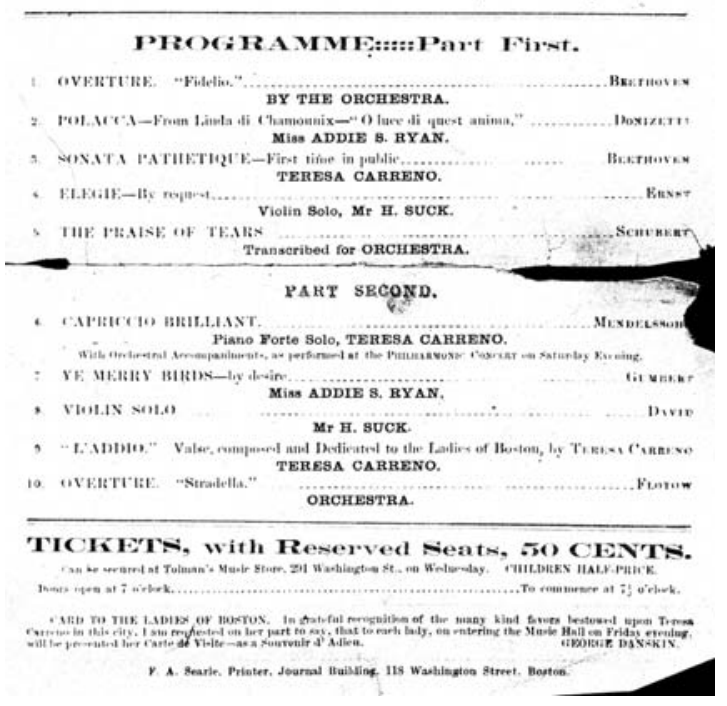

Fig. 2. Concert program, 30 January 1863 (Music Division, New York Public Library for the Performing Arts, Astor, Lenox, and Tilden Foundations, Clipping File, Carreño Programs $[\mathrm{MBD}-$ uncat $]$ ) 
Table 1. Works performed by Carreño on tour during 1862-66

\section{Composer}

Beethoven, Ludwig van

Carreño, Teresa

Chopin, Frédéric

Döhler, Theodor

Godefroid, Félix

Goria, Alexandre Édouard

Gottschalk, Louis M.

Herz, Henri

Hummel, Johann Nepomuk

Liszt, Franz

Mendelssohn, Felix

Prudent, Émile

Ravina, Jean Henri

Rossellen, Henri

Thalberg, Sigismond

Winner, Septimus

\section{Composition}

Piano Sonata no. 8, op. 13

Piano Sonata no. 14, op. 27, no. 2 ("Moonlight")

L'addio valse

Ballade, op. 15

Caprice-Polka, op. 2

La Emilia danza

Reminiscences de Norma. Fantaisie, op. 14

Gottschalk Waltz, op. 1

Impromptu [possibly "Une Larme." Impromptu, op. 5]

Marche triomphale, op. 8

Saludo a Cuba

Star Spangled Banner (improvisation)

Nocturne in E-flat

Nocturne

Nuits d'Espagne, op. 40, E minor

Fantasia on "Il trovatore," op. 77

Souvenir d" "Il trovatore" de Verdi, op. 79

Le bananier

Capricho [Español]

Dying Poet

Jerusalem

Last Hope

Marche de nuit

"Miserere" from "Il trovatore"

Printemps d'amour, op. 40

Grand Fantasia on Bellini's "I Puritani"

Rondo brillant, op. 98

Fantasy on "Lucia di Lammermoor"

Paraphrase de concert sur "Rigoletto," S. 434

Réminiscences de "Lucia di Lammermoor, " S. 397

Andante

Capriccio brillant, op. 22

Rondo capriccioso, op. 14

Caprice sur "Ernani," op. 31

Fantasia on Donizetti's "Lucia di Lammermoor," op. 8

Nocturne, op. 13

Fantasia on Verdi's "I due Foscari"

Barcarolla

Fantasia on Meyerbeer's "Les Huguenots," op. 20

Fantasia on Rossini's "Moses," op. 33

Grand Caprice on "La sonnambula"

Grand Fantasia and Variations on Bellini's "Norma," op. 12

Grand Fantasia and Variations on Mozart's "Don Juan," op. 14

Variations on "Home! Sweet Home!," op. 72

Listen to the Mocking Bird 
switching steamships midtrip due to mechanical problems. ${ }^{12}$ She made her European debut at the Salle Érard on 14 May 1866, with a program that included Thalberg's Grande fantaisie sur "Moise" and Gottschalk's Miserere du "Trovatore," op. 52. ${ }^{13}$ The music critic for L'art musical wrote, "Miss Carreno, whose arrival we announced in our last issue; she has transported the audience, and it is no small thing to succeed with so much brilliancy alongside Vivier. Miss Carreno is simply a genius." ${ }^{14}$ It was during her first few weeks in Paris that Carreño met composers Gioachino Rossini (1792-1868) and Franz Liszt (1811-1886)..$^{15}$

Her appearances in Paris were followed by concerts in London at St. James's Minor Hall and other venues during the summer months of 1866. It is difficult to imagine how she found the time to compose, given her studies, piano practice, concerts, and travel, but she did, producing works for piano including Reverie-Impromptu, op. 3, Caprice-Polka, op. 2, Fantasie-Caprice, and Souvenirs de l'Angleterre: Air anglais, op. 16. By the age of twelve, Carreño's musical talents and accomplishments were regularly reported in European, British, and American newspapers, such as Le ménestral, Neue Berliner Musikzeitung, La época, the Musical World, and the New York Times. Unfortunately, before she could extend her tour to Madrid, her mother died of cholera in September 1866.

She published most of her compositions between 1863 and 1873, a twelve-year period beginning with her arrival in the United States as an eight-year-old prodigy and ending shortly before her father's death in 1874, when she was twenty. This period of intense activity did not occur by chance. Her father went to great lengths to promote her musical talents as a pianist and composer and is the one who likely supplied most of the biographical facts and performance details reprinted in newspapers during her early musical career. He also filled the role of archivist, documenting his daughter's performance reception and output in the form of a curated scrapbook and fair-copy manuscripts. ${ }^{16}$

During her years in France and England, Carreño extended her repertoire of the early and mid-1860s to feature many of her newly composed

12. A notice appeared in the New York Times (3 May 1866, 8), describing the issues with the steamship City of Washington, which left New York on March 31. Due to mechanical problems, passengers were transported to the Propontis, arriving in Liverpool on 27 April 1866.

13. L' art musical, 17 May 1866, 190.

14. “Mlle Carreno, dont nous avons annoncé l'arrivée dans notre dernier numéro; elle a transporté l'auditoire, et à côtè de Vivier ce n'est point peu de chose que de réussir avec autant d'éclat. Mlle Carreno est tout bonnement un génie." Ibid.

15. Figaro programme, 23 March 1866.

16. There are two scrapbooks containing periodical clippings. The first was compiled by Carreño's father, the second by Carreño. The collected clippings are taken from periodicals in English, Spanish, and French. Those from 1862-68 are arranged chronologically and include annotations, while those from 1872-85 are unorganized. Teresa Carreño Papers, folder 11.1, scrapbook 1, May 1862-July 1868; and folder 12.1, scrapbook 2, 1872-85. 
and published works (fig. 3). Her performances also often included Beethoven's Piano Sonata no. 14, op. 27, no. 2; Liszt's Réminiscences de "Lucia di Lammermoor," S. 397; Chopin's Ballade no. 3, op. 47, and Polonaise, op. 26, no. 1; Carreño's Reverie-Impromptu, op. 3, Reminiscences de "Norma": Fantaisie, op. 14, Scherzo-Caprice, op. 31, Fantasie sur "L'africaine" de Meyerbeer, op. 24, Une revue a Prague: Caprice de concert, op. 27, Le printemps: 3ème valse de salon, op. 25, and Un rêve en mer: Étudeméditation, op. 28; Gottschalk's Miserere du “Trovatore," op. 52; Adolfo Fumagalli’s Rêverie “A une fleur”; Alfred Quidant's Grande etude-galop, op. 21; and Mendelssohn's Rondo capriccioso, op. 14, and Capriccio brillant, op. 22.

Following her mother's death, Teresa gave a series of concerts in Spain before bouncing back and forth between France and England for performances in 1867-69. During the spring and summer season of 1868, she made several appearances in London, including at Arthur Chappell's Popular Concerts. She resided with the James Bischoff family while her father remained in Paris. Teresa also joined the Maurice Strakosch troupe on a tour of cities across Europe and appeared in several performances in England during the summer of 1869 under conductor Julius Benedict. For her concerts in London in June 1869, she appeared with a violinist and cellist with the surnames Ries and Daubert, respectively, performing Mendelssohn's Piano Trio no. 1, op. 49. She also performed Beethoven's Piano Sonata no. 8, op. 13, Mendelssohn's Rondo capriccioso, her own Polonaise, op. 35, a set of Charles Levy and Charles Gounod's romances, and Liszt's Paraphrase de concert sur "Rigoletto," S. 434. ${ }^{17}$

During these years, she appeared on programs with many musicians with whom she would form lasting friendships and future musical partnerships, including American operatic soprano Minnie Hauck (18511929), Swedish operatic soprano Christina Nilsson (1843-1921), French composer, organist, conductor, and pianist Camille Saint-Saëns (18351921), Italian-French opera singer Adelina Patti (1843-1919), soprano Thérèse Tietjens (1831-1877), and Russian soprano Herminia Rudersdorff (1822-1882). With the onset of the Franco-Prussian War (1870-71) and through 1872, Teresa's performances were limited to England, Scotland, and Ireland, with appearances primarily under the management of Colonel Henry Mapleson as part of the M. Rivière Promenade Concerts at Covent Garden, and in recitals accompanied by Maurice Strakosch.

By the age of eighteen, Carreño was developing into an excellent musician. She added serious repertoire that was not only for show or variety and that took advantage of the availability of professional orchestras and ensembles-works such as Mendelssohn's Piano Concerto no. 1, op. 25, 


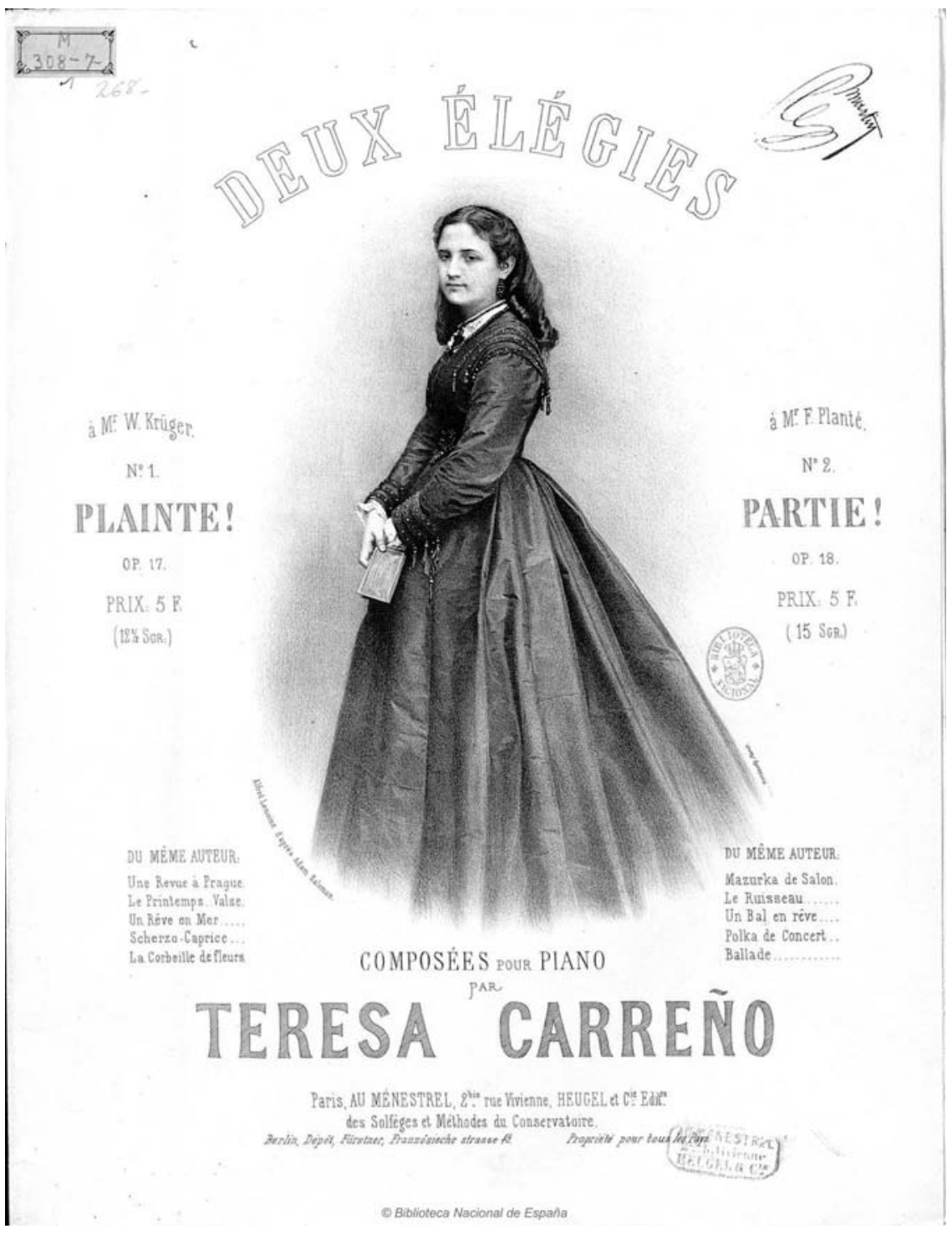

Fig. 3. Cover of Deux élégies, op. 17 and 18 (Paris: Heugel, ca. 1869) http://bdh.bne.es /bnesearch/detalle/3780238\#

Beethoven's Piano Concerto no. 5, op. 73, and Mozart's Piano Quartet no. 1 in G Minor, K. 478. By December 1871, Carreño was making appearances at the Monday Popular Concerts in London along with worldclass artists, including German pianist and composer Clara Schumann 
(1819-1896), Hungarian violinist, conductor, composer, and teacher Joseph Joachim (1831-1907), Adelina Patti, and Anglo-German pianist and conductor Charles Hallé (1819-95). During the winter/spring season of 1872, Carreño made her first appearance as a pianist in Ireland and Scotland, performing with numerous artists, including soprano Thérèse Tietjens and F. H. Cowen, managed by Mapleson.

While the troupe was in Edinburgh, Tietjens was unable to perform an operatic role, so Carreño stepped up to the challenge, earning praise from a critic for the Orchestra, who wrote that "Mdlle. Teresa Carreno, the charming South American pianist, has foresworn instrumental music and is now learning singing from Signor Fontana. She has a fine pure high soprano voice, and during Mr. Mapleson's recent tour she sustained the role of Marguerite de Valois in the Huguenots very successfully, though it was her début as an operatic vocalist, and she only sang on a sudden emergency." 18 As a pianist, Carreño's opportunities for demonstrating her technical capabilities and varied repertoire continued when, in the spring of 1872, she appeared as a featured soloist at the Hanover Square Rooms with accompanying musicians, performing works including ballades by Chopin and Gottschalk (opus numbers unidentified), her own Une revue a Prague: Caprice de concert, and Schumann's Andante und Variationen for two pianos, op. $46 .{ }^{19}$

\section{RETURN TO THE UNITED STATES AND ENGLAND (1872-76)}

In early September 1872, Carreño was aboard a steamer with the Max Strakosch troupe headed for New York City. Strakosch had organized a series of concerts that would begin in New York City at Steinway Hall on 16 September 1872, with stops along the East Coast and through the midwestern and southern states, and end in April 1873, when the artists would return to London. The troupe featured operatic soprano Carlotta Patti (1835-1889), American singer Annie Louise Cary (1842-1921), baritone Signor Del Puente, French violinist and composer Émile Sauret (1852-1920), and Italian tenor Giovanni Matteo de Candia Mario (18101883). It was most likely during this trip to the United States that Carreño became acquainted with Edward MacDowell's family and formed a lifelong friendship with Edward's parents, Thomas and Frances ("Fanny"), who filled the role of surrogate parents following the death of her mother, and eventually her father. ${ }^{20}$ She gave Edward several piano

\footnotetext{
18. Orchestra, 22 March 1872, 392.

19. Musical World, 25 May 1872, 333.

20. It is uncertain when the MacDowells met Carreño, but it is possible they met her parents during the 1860 s through a mutual friend, Juan Buitrago. See also Douglas E. Bomberger, MacDowell (New York: Oxford University Press, 2013), 17.
} 
lessons during his youth and actively championed his compositions and talents as a musician and composer, performing his works from the 1880s until her death in 1917. This was also the first time she publically endorsed the Weber Piano Company in a letter printed in newspapers, including the San Francisco's Daily Evening Bulletin:

Dear Mr. Weber-On my return to America after an absence of nine years, when as a "child pianist," I had traveled over this continent, I was struck with the wonderful progress in every department of art, but particularly in the manufacture of pianos.

My use of the Weber Piano, at over one hundred concerts, with the Patti and Mario troupe, assures you how highly I esteem them, and is really the highest compliment I can pay them. I am not surprised at the fact that every great artist prefers them, for they are truly noble instruments in tone, having a touch which meets every requirement of the most exacting artist, and their endurance and keeping in tone has often surprised me.

Accept my warmest compliments for your pianos, and my sincere thanks for your kindness in furnishing me with such delightful instruments.

Believe me, dear Mr. Weber, yours truly,

Teresa Carreno ${ }^{21}$

During her travels with the Strakosch concert troupe, Carreño became romantically involved with Émile Sauret, and they were married on 13 July 1873, following their return to London, possibly without the blessing of her father, who had remained in Paris after Carreño left for London in 1867. Soon after they married, Carreño discovered she was pregnant with her first child. She kept up a full performance schedule through March 1874, however, with appearances in England with the Philharmonic Society, in the M. Rivière's Promenade Concerts and Monday Popular Concerts, and in venues such as Covent Garden and St. James's Hall. Their daughter Emilita was born on 23 March 1874, and by May, Carreño was back on the concert circuit, occasionally performing with her husband, such as their concert on 11 June 1874 at the Hanover Square Rooms, where she performed her own work Highland: Souvenir d'Écosse; Caprice, op. 38, and, with Sauret on violin, Sigismund Thalberg and Charles de Beriot's Grand duo concertant pour piano et violon sur des motifs de l'opéra "Les Huguenots," op. 43, and Beethoven's Violin Sonata no. 8 , op. 30 , no. 3.22

Carreño and Sauret planned to join the De Murska Concert Company on a tour of the United States and Canada for the 1874-75 season. This tour was managed by impresario Diego De Vivo and featured Croatian opera singer Ilma de Murska (Ema Pukšec; 1834-1889), often referred

21. Daily Evening Bulletin [San Francisco], 21 June 1873, 2.

22. Musical Standard, 20 June 1874, 403-4. 
to as the successor of Jenny Lind. ${ }^{23}$ Before setting off on this tour, Carreño faced a challenge: What would she do with her five-month-old daughter Emilita? To complicate matters, her father died on 24 August 1874, shortly before their departure for the United States. Carreño was used to long hours of travel, practice, and study, as well as numerous concert performances, but now she had to balance her duties as wife, mother, and musician without any familial assistance. This must have been a challenge for her, and it may explain her decision to leave her daughter in the care of Mrs. James Bischoff in England while she embarked on the tour. A grueling tour was not a friendly environment for an infant, and with no home base in the United States, Carreño may have made this decision out of desperation and with the best interests of her child in mind. It was, however, a choice she was to regret later in life.

In December 1874, the tour brought the couple up the East Coast on their way to Canada, giving Carreño a chance to visit with the MacDowell family in New York City on 26 December 1874. She was preparing for her debut as Zerlina in Mozart's Don Giovanni under the guidance of Herminia Rudersdorff, a singer with whom she had the pleasure of performing in 1868-69.24 This tour also brought Carreño to the West Coast for the first time, with concerts in San Francisco and Los Angeles during the spring of 1875. After the final concerts in Carson City, Nevada, in August, the couple returned to New York City. ${ }^{25}$

\section{THE YEARS IN THE UNITED STATES (1876-89)}

In December 1875, only a few months after the end of the tour, Carreño was back on the road with the Tietjens Troupe, managed by Max Strakosch and featuring operatic soprano Thérèse Tietjens. It was during this tour that Carreño made her US operatic debut, on 25 February 1876 in New York City, in the role of Zerlina in Don Giovanni. Her performance was admired by the critic for Dwight's Journal of Music, who wrote, "The debutante of the evening, the beautiful Mme. CarrenoSauret, in the part of Zerlina, acted with grace and spirit, and in spite of the indulgence asked for her on the ground of health, sang most of the music well, showing herself the possessor of a clear, rich, telling voice, which seems to promise a career."26

According to Marta Milinowski, Carreño was expecting another child. ${ }^{27}$ The couple's ongoing disagreements and the prospect of a new

23. New York Herald, 13 September 1874, 4.

24. Bomberger, 22.

25. Carreño's 1875 California tour is discussed in item L154.

26. Dwight's Journal of Music, 18 March 1876, 199.

27. Marta Milinowski, Teresa Carreño: "By the Grace of God" (New Haven: Yale University Press, 1940, $116-17$. 
baby were too much for Sauret. By the end of 1876 their marriage had deteriorated, and Sauret deserted Carreño. Years later, when Carreño responded to handwritten interview questions posed by Ida Marie Lipsius (1837-1927), she noted that Sauret had left a few weeks before the birth of the child. ${ }^{28}$ She does not say whether the child survived birth, but the child is not mentioned in any of her correspondence or documents related to her surviving children.

During 1876, Carreño received correspondence from Mrs. James Bischoff requesting official permission to adopt Emilita, the daughter she had left in her care in 1874. She agreed to Mrs. James Bischoff's request. In addition to the dissolution of her marriage and the loss of a child, Carreño had given up her rights to her first child-a decision that must not have been easy to make, but due to her position as a single, soon-to-be-divorced woman and sole bread winner, she may have felt that it was in the best interest of her child. ${ }^{29}$

Carreño's performances during the fall of 1876 through the spring of 1877 were limited largely to the East Coast and featured performances with American operatic soprano Emma Abbott (1850-1891), American singer Emma C. Thursby (1845-1931), her husband, violinist Émile Sauret, Norwegian violinist Ole Bull (1810-1880), and Italian baritone Giovanni Tagliapietra (1845-1921). In April 1877, Carreño and Tagliapietra participated in the Telephone Concerts at the Academy of Music in Brooklyn and at Steinway Hall in New York City. These concerts were managed by Maurice Strakosch and advertised as "the first public performances of Professor Elisha Gray's marvelous Telephone" where "[m] usical melodies will be performed in Philadelphia and distinctly heard by the audience in New York." 30 Following the April 4th performance, a critic for the New York Herald wrote, "The experiments at Steinway Hall last night were quite successful, and the audience, which was large, evinced their interest by hearty and continued applause. The atmospheric conditions seemed to be excellent, and the tones were audible and clear." 31 On this occasion, Carreño performed Mendelssohn's Rondo capriccioso, Chopin's Barcarolle, op. 60, and Liszt's Paraphrase de concert sur "Rigoletto." Another important concert took place at Steinway Hall on 23 November 1877, in which Carreño performed Mendelssohn's Piano Concerto no. 1 with the Theodore Thomas Orchestra. ${ }^{32}$

\footnotetext{
28. Correspondence between Ida Marie Lipsius and Carreño (post-1895), 15-16. Invnr.: A/166/201. La Mara-Nachlass, Stadtgeschichtliches Museum, Leipzig.

29. See Bomberger, 103. According to Milinowski (117), Carreño agreed to relinquish all rights over her child and to never request visitation. Milinowski does not state where she received this information nor does she cite a letter or legal document.

30. New York Herald, 1 April 1877, 4.

31. New York Herald, 5 April 1877, 7.

32. New York Herald, 22 November 1877, 1.
} 
Carreño and Tagliapietra continued to perform on shared programs through the spring of 1877 , and their professional relationship turned romantic; by early summer, Carreño was pregnant with another child. At some point before the birth of Louisa "Lulu" Tagliapietra on 1 March 1878, the couple moved into a house in New Rochelle, New York, an ideally located, quiet town with easy travel routes via coach, rail, and water to New York City, and a popular vacation spot for city dwellers. It had a growing population of French and German immigrants and must have seemed the perfect location for a couple to escape and start a new chapter in their lives.

Carreño was still married to Sauret, who could have sued her and claimed legal rights to her child. These circumstances may have led Carreño and Tagliapietra to live under the assumed surname of "Gurian" (see fig. 4). ${ }^{33}$ Carreño did not curtail her performance schedule until about a month before Lulu's birth, after which she remained home with her infant through the summer months. While Carreño cherished her role as mother, Tagliapietra returned to the concert circuit to maintain a steady stream of income. By August 1878, Carreño returned to the stage in Saratoga Springs, New York, and Newport, Rhode Island-locations that catered to wealthy visitors escaping the city during the hot summer months.

During the next two concert seasons, between 1878 and 1880, Carreño traveled and performed in the eastern, southern, and midwestern United States with artists including Ilma de Murska, German violinist August Wilhelmj (1845-1908), and American singer Kate Thayer. Carreño and Tagliapietra made appearances together between October 1879 and January 1880, primarily under the auspices of the Kate Thayer Concert Company (see fig. 5). In 1880, the couple, along with opera singer Mme. Donaldi, formed the Carreño-Donaldi Opera Company, under which name they performed during 1881 and 1882.

During the remainder of the 1880 season, Carreño performed mainly around New York, with a few appearances in the Washington, DC, and Chicago areas. Following an appearance in a series of concerts at the Athenaeum Club in Washington, DC, the critic of the Sunday Herald wrote:

The feature, however, of this concert was the playing of Madame Theresa Carreno, who, added to her recognized ability as a performer upon the piano, is one of the most beautiful and fascinating women on the concert stage. As a performer she is not merely a mistress of technique, but she seems to feel the music she reads, and her feelings find expression from her fingers, and while

33. Sauret filed for divorce at the end of 1878. See under "Gurian" in the Tenth Census of the United States, 1880. Census place: New Rochelle, Westchester, New York. Roll 946, Family History Film 1254946, page 29D, enumeration district 115, image 0362. 


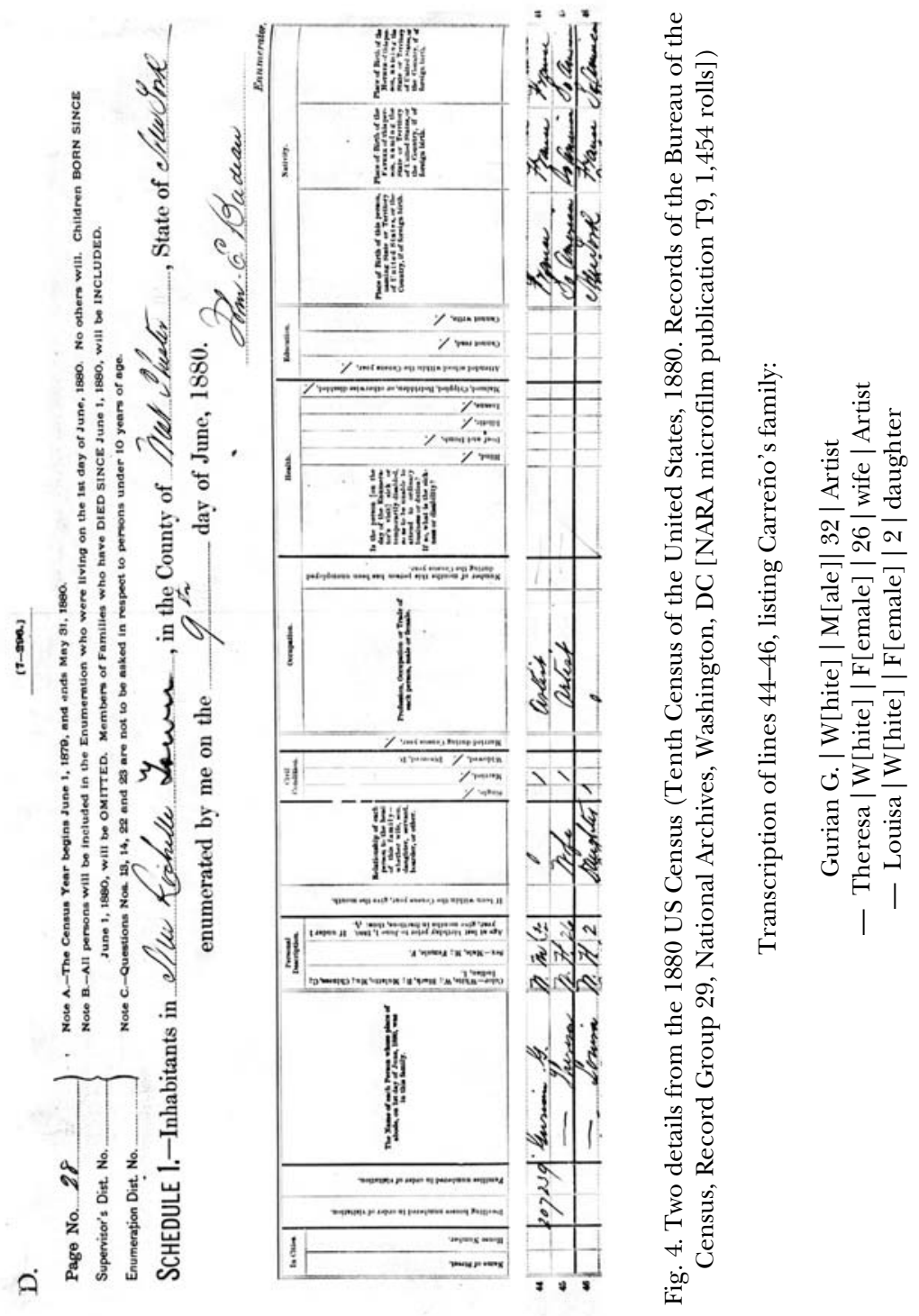




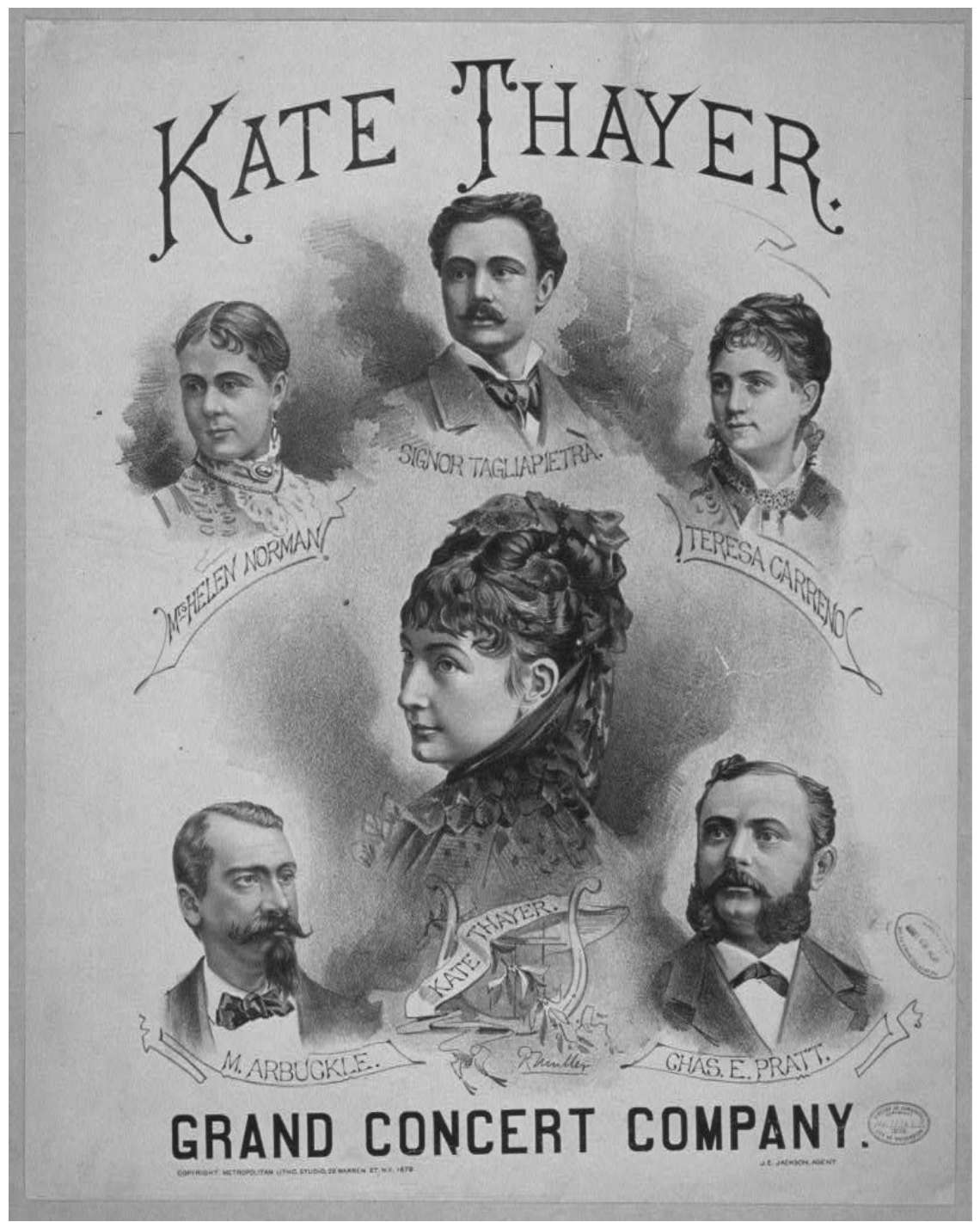

Fig. 5. Poster of the Kate Thayer Concert Company (New York: Metropolitan Litho. Studio, ca. 1879). (Theatrical Poster Collection, POS-TH-MUS, no. 2 [B size], Prints and Photographs Division, Library of Congress) https://www.loc.gov/item/2014635557 
her touch has force and precision and every note struck upon the keyboard is clear cut, her scales are faultless and her arpeggios are unsurpassable in their harmonious effects. ${ }^{34}$

By this time, Carreño had outgrown her musical-prodigy status and had become a self-sufficient artist, performing tirelessly on the concert circuit, primarily as a secondary artist or accompanist. For the greater part of her life, Carreño was a public performer with only herself to rely on for financial means. The period from 1874 through the early $1880 \mathrm{~s}$ was no different. Her only other income at various points would be from teaching, but that was negligible compared to concert earnings. During this time, she was not the featured artist on programs and often did not get more than a line of praise in a review, which must have been disappointing. The artists who headlined these tours were primarily opera singers: Ilma De Murska, Adelina Patti, Clara Louise Kellogg (18421916), Emma Abbott, Adelaide Phillipps (1833-1882), and Emma Thurston, among others. Or they were visiting soloists, such as August Wilhelmj, Henryk Wieniawski (1835-1880), or Anton Rubinstein (18291894). These musicians were heavily advertised, promoted, generously paid (in comparison to the other artists on the bill), and garnered lengthy reviews. By the 1880s, however, Carreño's musical abilities were beginning to gain recognition once more, especially when she was given the chance to shine as a featured artist.

Carreño was one of many pianists touring the country at this time. Others included Julie Rivé-King (1834-1937), Fannie Bloomfield Zeisler (1863-1927), Anna Yesipova (Annetta Essipoff; 1851-1914), Hans von Bülow (1830-1894), and Anton Rubinstein. While positive reviews captured her character and quality at the piano-often portraying her similarly to other foreign-born pianists-there was a difference that could not be overlooked. These other artists had been trained abroad (in Germany, France, and Russia) and had made their debuts in European capitals. As Jessica C. Gienow-Hecht observes:

After the German Revolution of 1848, Americans were for the first time exposed to a massive influx of European musicians, most of whom came from the German states. While many artists fled Europe for political reasons, an even greater number felt that its concert stages did not look as promising or safe after 1848 as before. Consequently, touring the United States became the fashion, even though at that time its musical landscape more closely resembled a circus than any higher form of entertainment. ${ }^{35}$

34. Sunday Herald [Washington, DC], 4 April 1880, 1.

35. Jessica C. E. Gienow-Hecht, Sound Diplomacy: Music and Emotions in Transatlantic Relations, 18501920 (Chicago: University of Chicago, 2009), 53. 
In contrast, Carreño was Venezuelan, yet often labeled "American." She had made her New York debut without extensive training in Europe. Although we might think this should have no bearing on her career if her skills and execution were equal to or beyond that of these artists, critics and concertgoers of the nineteenth and early twentieth centuries still held onto the thinking that one has not reached musical maturity or a high level of status until you have trained and debuted in France or Germany.

The years of touring - often as a secondary artist, especially during the 1870s—had taken a toll on Carreño. The personal losses she incurred during the early 1870s were followed by another enormous loss in 1881 . While on tour during April 1881, Carreño learned her daughter Lulu was ill. She broke away from her tour after her concert on April 29 in Baltimore to be at Lulu's side, but the child died soon thereafter, on 16 May 1881, at the age of three years and two months. ${ }^{36}$

By the early 1880s, Carreño's repertoire had greatly expanded beyond the variety pieces by Gottschalk, Prudent, Thalberg, and Ravina. Her programs regularly included Chopin nocturnes, preludes, etudes, and waltzes; Grieg's Folkelivsbilder, op. 19; several of Liszt's Rhapsodies hongroises, S. 244; Beethoven's Piano Sonata no. 23, op. 57 (“Appassionata”); Schumann's Études symphoniques, op. 13, and selections from Fantasiestücke, op. 12; and MacDowell's First Modern Suite, op. 10, Serenade, op. 16, Second Modern Suite, op. 14, and other works by MacDowell. She had the opportunity to program these works and appear as a soloist under the auspices of her own troupe, the Carreño-Donaldi Opera Company. When the new Weber Warerooms were opened in Chicago, Carreño was the featured pianist, appearing on 2 February 1882. She no longer performed the variety pieces of her youth, but rather standards that she would retain on her programs and the more technically difficult pieces that she would begin to take on in the late 1880s through the 1890s. Her repertoire for that evening included Schumann's Études symphoniques; Tchaikovsky's Romance in F; Rubinstein's Etude, op. 23, no. 2, and Grand valse in A flat; Chopin's Barcarolle; Carreño's Esquisses italiennes, No. 1: Venise, Réverie-Barcarolle, op. 33, and Le printemps: 3ème valse de salon, op. 25; Beethoven's Piano Sonata no. 13, op. 27, no. 1; and Liszt's Rhapsodie hongroise no. 2, S. 244/2. ${ }^{37}$

\footnotetext{
36. Her death is mentioned in the New York Herald, 17 May 1881, 11. Louisa is buried at the Beechwoods Cemetery (New Rochelle, NY), section 13, range 2, grave 2.

37. Herald (Chicago), 3 February 1882; Daily Inter Ocean (Chicago), 4 February 1882, 13.
} 
During the 1882-83 season, Carreño took a short break in November to prepare for the birth of another daughter, Teresita, who arrived on 24 December 1882. By the end of January, Carreño was concertizing once more, and in March 1883, she appeared with the Leopold Damrosch Orchestra performing Grieg's Piano Concerto in A Minor, op. 16, for the first time in her career. The critic for the Worcester Daily Spy praised her performance: "A beautiful composition by Grieg, a concerto, in which Mme. Terese [sic] Carreno at the piano showed that she had lost none of her wonderful command over that instrument, was finely done." 38 The critic for the Hartford Daily Courant wrote, "Mme. Carreno, who is an old and well-known favorite here surprised even those who know her best by her brilliant and masterly rendition of the pianoforte concerto by Grieg. The work is itself of great merit, and Mme. Carreno's conception and execution of it was one of the finest ever listened to in Hartford. She was recalled enthusiastically, as were the other soloists and the conductor upon nearly every appearance."39

On 8 March 1884, Carreño gave the first performance of Edward MacDowell's Second Modern Suite in Chicago. MacDowell was still largely unknown. The Chicago critics did not comment specifically on this work, writing only that "Mme. Carreno has delighted our musical people by her brilliant playing this week, both at the Beethoven Society concert and her own recital. She is a very enthusiastic player, imparting to her performances in richness and warmth of expression that is at times quite electrifying." ${ }^{40}$ Carreño promoted the works of MacDowell avidly and recommended him to music publishers and concert impresarios, as can be seen in a letter written on 3 July 1883, to Samuel Arthur Chappell, in which she reminds him of the kindness he showed her when she was an emerging artist.

The object of this, is to speak to you of a great and dear friend of mine, Mr. E. A. McDowell, a young man full of talent both as a pianist and composer and who has gained in Germany (where he has been for several years) great praise both from the press and the public.

He is very anxious to present himself before the English public and I come to ask you if you would kindly help him to appear in Concerts in London either in the coming winter or during the next Summer season. ${ }^{41}$

38. Worcester (Mass.) Daily Spy, 13 March 1883, 4.

39. Hartford (Conn.) Daily Courant, 17 March 1883, 3.

40. Chicago Daily Tribune, 9 March 1884, 17.

41. Letter from Carreño to Chappell, 3 July 1883. Library of Congress, Music Division, Edward and Marian MacDowell Collection, 1861-1960, ML31 .M198, box 43 (hereinafter cited as MacDowell Collection). 
Carreño includes MacDowell's address and mentions that Chappell may request information about him from his publisher, Breitkopf \& Härtel in Germany.

Between May and December 1884, Carreño was largely absent from the concert stage for unknown reasons. It is possible she chose to stay home to care for her toddler, Teresita, and to prepare for the birth of her first son, Giovanni, on 8 January 1885, while Tagliapietra performed across the United States to support the family. Following Giovanni's birth, Carreño resumed concerts during the spring of 1885 in the northeastern United States and Canada, sticking closer to home and her children, before ending the season with appearances in the midwestern and southern states. During these performances, she frequently performed MacDowell's compositions, including his Second Modern Suite and "Erzählung" and "Hexentanz" from 2 Fantasiestücke, op. 17.

In 1885, Carreño received an invitation from General Joaquín Crespo, the president of Venezuela, to give a series of concerts in her homeland and to consider forming an opera company. As early as May 1882, she had written to him about her desire to return to Venezuela and the financial support that would be needed to support the founding of an opera company. Carreño also envisioned forming an international music conservatory, plans for which she outlined in letters to Crespo's successor, Guzmán Blanco, in 1886. ${ }^{42}$ Tagliapietra and Carreño arrived in Caracas on 15 October 1885, and remained there through November 1886. Her first concert took place on October 27 at Teatro Guzmán Blanco, where she performed Chopin's Piano Concerto no. 1 in E Minor, op. 11, accompanied by a second piano and string quintet. Her composition Himno a Bolívar, dedicated to President Joaquín Crespo, was performed by "Señor Molina," with choir and orchestra. ${ }^{43}$ On 7 September 1886, Carreño again performed at Teatro Guzmán Blanco in a concert that included her composition Himno á Guzmán Blanco in honor of General Guzmán Blanco who would shortly succeed President Crespo in October 1886 (fig. 6).

Following their return to the United States in November 1886, Carreño stayed busy, appearing in concerts in the northeastern and midwestern United States and in Canada through the beginning of February before making a trip back to Venezuela. During this second trip, they set

42. Letters from Carreño to Antonio Leocadio Guzmán Blanco are housed in the Archivo Fundación John Boulton in Caracas, Venezuela. See letters dated 21 September and 4 October 1886, for information about a proposed conservatory.

43. See Mario Milanca Guzmán, "Dislates en la obra Teresa Carreño, de Marta Milinowski," Revista de música latinoamericana 8, no. 2 (1897): 185-215. A review of this concert appeared in El siglo, 29 October 1885,5 . 


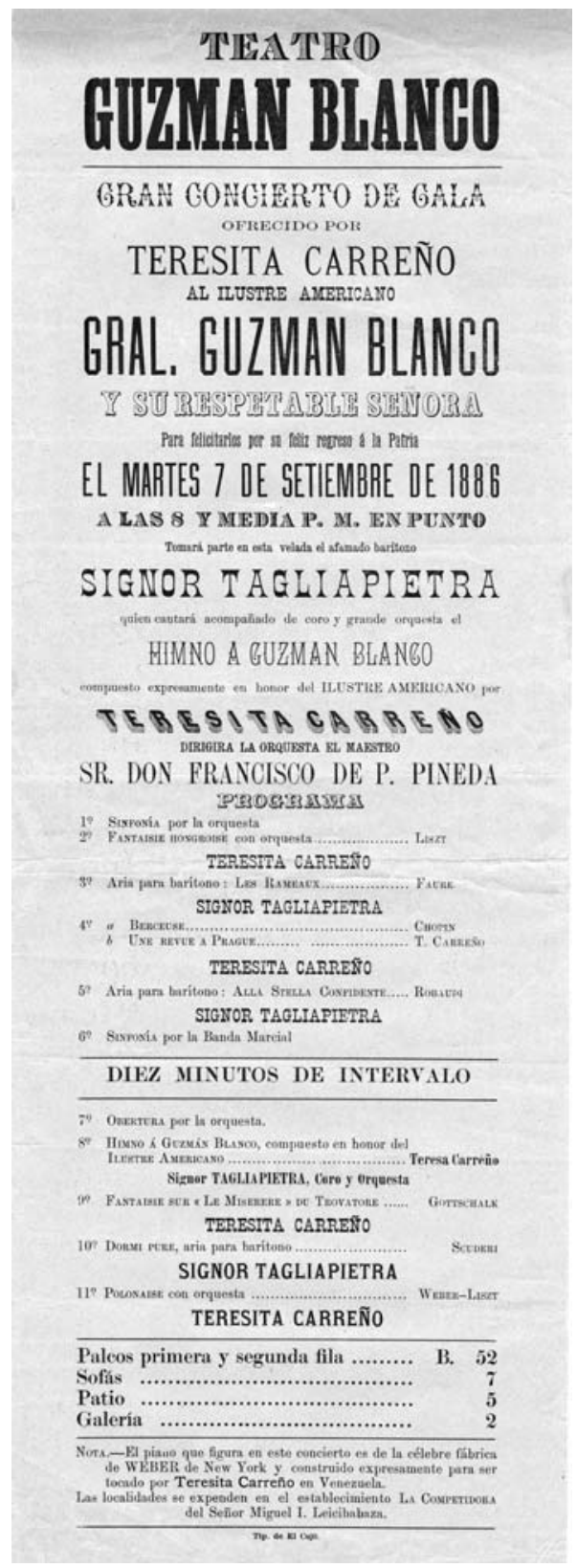

Fig. 6. Concert program, 7 September 1886 (Teresa Carreño Papers, folder 14.8: Concert Programs) 
up a national opera company with a group of foreign artists, including Italian soprano Teresina Brambilla (1845-1921), known as "La Brambilla." Unfortunately, the opera company was a failure, due to interferences from the political party, outbreaks of violence in Caracas, and the departure of the conductor, which required Carreño to step in and conduct several performances. Carreño had to beg Guzmán Blanco repeatedly for funds to cover the salaries of her artists and other costs. In addition to these financial difficulties, Carreño had to deal with a lawsuit filed by Adela Aiemry de Histar, a prima donna in the opera company, and she was unable to leave Venezuela until the suit was settled. ${ }^{44}$

News of the failed opera company appeared in foreign newspapers, including the French music journal Le ménestrel:

Artistic debacle in Caracas (Venezuela), where the opera troupe TagliapietraCareno [sic] took residency in the Guzman-Blanco theater to give, for two months, an Italian season. The theater opened with Un ballo in maschera [Verdi], with excellent results, but the other works were not to the satisfaction of the public, who, little by little, deserted the theater. Discouraged, the principal artists, one after another, abandoned the unfortunate director, who came to New York with his washed up troupe. There, he tells anyone who will listen, he was forced to bow before the susceptibilities of a population who was reluctant to attend an establishment bearing the name of President Guzman Blanco! 45

The odds seemed against Carreño, and once President Guzmán Blanco was ousted from Venezuela due to the political unrest, she returned to New York in August 1887.

Adding to the challenges she faced with the failed opera company in Venezuela, Carreño's relationship with Giovanni Tagliapietra was dissolving. Tagliapietra had a rough past with numerous legal issues. These included an 1876 lawsuit with Adelaide Phillipps's company and another in 1881 with the opera singer Marie Litta. The legal troubles surely had a negative effect on both their lives. ${ }^{46}$ Also, both were known for their tempers and stubborn natures, often resulting in domestic disputes that led

44. See letters from Carreño to Antonio Leocadio Guzmán Blanco written on 17 June and 25 July 1887. Archivo Fundación John Boulton.

45. "Débâcle artistique à Caracas (Venezuela), où la troupe d'opéra Tagliapietra-Careno avait pris possession du théâtre Guzman-Blanco pour y donner, pendant deux mois, une saison italienne. L'ouverture se fit avec un Ballo in maschera, qui donna d'excellents résultats, mais les autres ouvrages ne satisfirent pas le public qui, petit à petit, déserta le théâtre. Découragés, les principaux artistes se mirent à leur tour à abandonner, l'un après l'autre, l'infortuné directeur, qui vint échouer à New-York avec les débris de sa troupe. Là-bas, il raconte à qui veut l'entendre qu'il a été forcé de plier devant les susceptibilités d'une population à qui il répugnait de fréquenter un établissement portant le nom du président Guzman Blanco!" Le ménestrel, 5 June 1887, 214. http://gallica.bnf.fr/ark:/12148/bpt6k5615345w.

46. See for example the Chicago Daily Tribune, 6 January 1876, 5, and 29 October 1881, 8. His legal issues may have also been a factor in deciding to live under the assumed name "Gurian" in New Rochelle, NY. 
to violent acts by Tagliapietra against Carreño. His actions against her are documented in a 6 September 1901 letter from Fanny MacDowell: Tagliapietra "decorated you with black eyes and bloody nose more than once!" 47 Upon her return to New York, the family moved from New Rochelle to 207 East 18th Street in New York City, a location nearer to her close friends Fanny and Thomas MacDowell, whose support she would undoubtedly need during the next few years.

During the 1887-88 season, Carreño appeared predominantly as a soloist or featured artist, and she performed in several concerts with the Boston Symphony Orchestra directed by Austrian-born conductor Wilhelm Gericke (1845-1925), including one in October in which she performed Chopin's Piano Concerto no. $1 .{ }^{48}$ Encouraged by her friend, pianist, and teacher Regina Watson (1845-1913) as well as Fanny, Carreño began adding a steady group of concertos to her repertoire, most likely in preparation for her planned Berlin debut in 1889. Among the works she began performing regularly with orchestras are Godard's Concerto romantique, MacDowell's Piano Concertos nos. 1 and 2, and Saint-Saëns's Piano Concerto no. 4.

By 1888 , she had borrowed $\$ 5,000$ from N. K. Fairbank, an American industrialist, to finance her relocation and startup costs in Berlin. ${ }^{49}$ She had met Fairbank through her friend and mentor Regina Watson, whose students included Helen, Fairbank's daughter. Carreño continued to premiere MacDowell's compositions during her tours in 1888 and 1889. At Weber Music Hall in Chicago on 15 February 1888, she performed his Etude de concert, op. 36, among other works, including Saint-Saëns's Cello Sonata no.1, op. 32 (with cellist Hans Hess); Chopin's Nocturne, op. 37, no. 1, Mazurka, op. 33, no. 4, "March Funèbre" from Piano Sonata no. 2, op. 35, and Tarantelle, op. 43; Beethoven's Andante favori, WoO 57; Tchaikovsky's Romance; Rubinstein's Le bal, op. 14; Vogrich's Staccato caprice; and Gottschalk's Apothéose, op. 29.50 During the summer months, she appeared at the Music Teachers' National Association Convention in Chicago, where she gave the Chicago premiere of MacDowell's Piano Concerto no. 1 on July 5 with the Theodore Thomas Orchestra and garnered much appreciation from the audience. A critic for the Daily Inter Ocean praised her performance:

47. Letter from Frances MacDowell to Carreño, 6 September 1901. Teresa Carreño Papers, series 3: Correspondence, folder 8.11 .

48. Boston Daily Globe, 30 October 1887, 4.

49. A few years after her successful performances across Europe, Carreño received a letter from Fairbank acknowledging her repayment of the $\$ 5,000$ loan. Letter from N. K. Fairbank to Carreño. September 30 [between 1892 and 1894]. Teresa Carreño Papers, series 3: Correspondence, folder 9.12.

50. Daily Inter Ocean (Chicago), 16 February 1888, 4. 
As a pianist Mme. Teresa Carreno showed fine technique and consummate grace in Mac Dowell's concerted piece in A minor, triple movement, from allegro to presto. ... Mme. Carreno brought hundreds to their feet for a set glance at this famous queen of the pianoforte. Indeed, it seemed as if Carreno were the attraction of the performance, so cordially was she greeted and studied. When she concluded and did not reappear in response to the genuine volley of hand-clapping many considered their cup for the evening full. ${ }^{51}$

September through November 1888 kept her mostly in the northeastern states before she moved to the Midwest in December. Carreño appeared on occasion with Tagliapietra during the spring of 1889; these concerts were interspersed with appearances as a soloist with or without orchestra. By late spring and early summer 1889, news of Carreño's intended departure for Europe was being disseminated in the national papers. On June 19, the Daily Inter Ocean announced:

The numerous friends of Mme. Carreno will be interested to know that she will shortly leave for Europe, to be absent several years. Previous to her departure she will appear in a grand testimonial concert under the auspices of the Amateur Musical Club. This concert will take place at Central Music Hall on Friday evening next, at 8 o'clock. Mme. Carreno will give one of her best performances and will be assisted by Mr. Gottschalk. It is hoped her many friends will unite in making this occasion a complete success financially, as it certainly will be, artistically. ${ }^{52}$

And by the fall, music journals were announcing, albeit slightly incorrectly, the repertoire that she would perform for her Berlin debut: Chopin's Piano Concerto no. 1 in addition to shorter piano works, such as Franz Schubert's Marche militaire, D. 733, no. 1 (arr. Tausig), and Carl Maria von Weber's Polacca brillante, op. 72 (arr. Liszt). ${ }^{53}$

\section{ACHIEVING WORLD-RENOWNED STATUS (1889-95)}

In July 1889, Carreño set sail for Germany by way of England on the steamer Galli with her children Teresita and Giovanni. Jessica GienowHecht writes that "for all the traveling virtuosos, singers, bands, and agencies in the United States, Frank Damrosch's criticism in regard to its 'musical darkness' contained a grain of truth: Americans wishing to partake in the music circuit had to travel to Germany in order to study music in earnest. Until about 1860, musicians wishing to embark on a solo career had to receive 'le bapteme de Paris' to seal their success." 54

\footnotetext{
51. Daily Inter Ocean (Chicago), 6 July 1888, 4.

52. Daily Inter Ocean (Chicago), 19 June 1889, 4.

53. Etude, October 1889, 151.

54. Gienow-Hecht, 54.
} 
Over time, that changed. "Berlin gradually replaced Paris as the center of musical approbation. ${ }^{55}$ On her way to establishing herself as a worldrenowned concert pianist, Carreño settled in at the Askanischer Hof in Berlin and began her concert appearances under representation of the prestigious German concert manager Hermann Wolff (1845-1902). On 18 November 1889, Carreño made her debut with the Berlin Philharmonic Orchestra under conductor Gustav F. Kogel (1860-1947) at the Singakademie (see fig. 7), performing Edvard Grieg's Piano Concerto, Schumann's Zwölf symphonische Etüden, op. 13, and Weber's Polonaise brillante (arr. Franz Liszt). ${ }^{56}$ The music critic for the Neue Berliner Musikzeitung described her as a "warmblütige venezuelische Künstlerin" (warmblooded Venezuelan pianist) who was new to Germany. He praised her demonstration of technique in all three compositions, as well as her power and energy-especially in the Schumann-but pointed out that she lacked the more feminine or softer tones in her performance. ${ }^{57}$

Despite the somewhat mixed review, Carreño made an incredible impression on the Berlin public, and her reputation as a powerful, virtuosic performer would grow as she toured across Europe for the next seven years before returning to the United States. In contrast to her US concert tours during the 1870s and 1880s, Carreño was the featured artist on programs in Europe. The concertos she performed included the Beethoven no. 5, Grieg, MacDowell nos. 1 and 2, and Chopin no. 1. She soon began adding others, including the Saint-Saëns no. 4; Tchaikovsky no. 1, op. 23; d'Albert no. 2, op. 12; and Rubinstein no. 4 in D Minor, op. 70.

Carreño's hopes for a new life in Berlin must have included dreams of being reunited with her first daughter, Emilita, whom she had given up for adoption to the Bischoff family in $1876 . .^{58}$ The Bischoffs lived in Wiesbaden, and a concert in this same city presented an opportunity for Carreño to request a visit. On 19 February 1890, Carreño wrote to Mrs. Bischoff:

On the 21st instant I go to Wiesbaden to fulfill a Concert engagement, and I come to beg most earnestly of you to allow me to see my daughter for a few minutes.

I think that in all these years of a silence so painful to me, in which I have longed oh! with such a heavy heart! to hear something of my child without in any way causing you or her any pain, I have sufficiently proved to you how thoroughly I wished you to keep all my rights over her, (for this was the promise I made to myself), so that she would grow loving you with all her

\footnotetext{
55. Ibid.

56. Neue Berliner Musikzeitung 43, no. 48 (28 November 1889): 393.

57. Ibid.

58. Her daughter's married name was Emilita Tauscher.
} 
Montag, den 18. November 1889 , Abends $7 \frac{1}{2}$ Uhr präcise:

Im Saal der Singakademie

\section{CONCERT}

von

\section{Teresa Carreño}

mit den

Berliner Philharmonischen Orchester

unter Leitung des

Herrn Kapellmeister Gustav F. Kogel.

PROGRAMM.

1. Ouverture zum ,Märchen von der schönen

Melusine", op. 32 . . . . . . F. Mendelssohn.

2. Concert für Klavier mit Begleitung des Or-

chesters A-moll, op. 16 . . . . . Ed. Grieg.

Allegro molto moderato. - Adagio. -

Allegro moderato molto e marcato quasi Presto.

3. Zwölf symphonische Etüden, op. 13. . R. Schumann.

4. Andante für Streichquartett . . . . . . P. Tschaikowsky.

5. Polonaise brillante f. Klavier mitBegleitung

des Orchesters. . . . . . . . . Weber-Liszt.

\section{Concertflügel: Bechstein.}

Während der Musik bleiben die Saalthïren geschlossen.

Billets a 5, 3 und 2 Mark sind in der Hof-Musikhandlung der Herren

Ed. Bote \& 6. Bock, Leipziger Str. 37, sowie Abends an der Kasse zu haben.

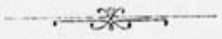

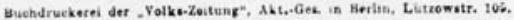

Fig. 7. Concert program, 18 November 1889 (Teresa Carreño Papers, folder 14.11: Concert Programs) 
heart and undisturbed by the thought of her unfortunate and unhappy mother. I still intend to keep this promise, for more than ever am I convinced that for the child's own sake, I acted right, and if, she does not know who I am, and what my relation to her is, I will never tell her, for her own sake, but I can-not come so near her, longing as I do for one look at her, and not see her. . . . 59

Unfortunately, her request for a visit was not granted. This must have been a disappointment to Carreño, but she kept busy moving forward with concerts during the spring of 1890 , followed by a full 1890-91 concert season, which took her to cities across Europe and England and included several stops in Russia. During these concerts-and throughout the rest of her career-she regularly performed Grieg's Piano Concertoincluding performances under Hans von Bülow and even Grieg himself (in 1893) - and gradually introduced the European public to MacDowell's compositions, including his Piano Concerto no. 1, performed at the Singakademie under conductor Gustav F. Kogel on 13 February $1890 .{ }^{60}$ Following her first Berlin performance of the concerto, she wrote MacDowell about its immense success and added that she had discussed his compositions with the conductor, Gustav F. Kogel, and shared his address with him. She advised MacDowell to contact Hans von Bülow, who would be traveling to Boston. ${ }^{61}$

At some point during the 1890-91 season, Carreño met Scottish-born, German pianist and composer Eugen d'Albert (1864-1932)-possibly through her manager Hermann Wolff and his wife Louise-and in the fall of 1891 they moved into Villa Teresa in Coswig, Germany, about ten miles from Dresden. In the spring of 1892, d'Albert traveled without Carreño to the United States for a tour with Hungarian conductor Arthur Nikisch (1855-1922). While d'Albert was away, Carreño discovered she was pregnant. On 24 June 1892, Carreño received a letter from Fanny MacDowell, who referred to a letter Carreño had sent her in which she described her relationship with d'Albert and the joy and happiness she felt. ${ }^{62}$ About a month later, during their trip to England, Carreño and d'Albert were married on July 27, and two months later, on

\footnotetext{
59. Letter (including drafts) written by Carreño to Mrs. Bischoff, 19 February 1890. Teresa Carreño Papers, series 3: Correspondence, folder 9.12. Milinowski (200) quotes from a letter from Bischoff's lawyer to Teresa dated 24 February 1890, in which he refuses her request for a visit. Milinowski does not provide details about the letter's location.

60. For example, see the review of the 31 January 1890, concert in the Neue Berliner Musikzeitung 44, no. 6 (6 March 1890): 50-51. See brief announcement for the 13 February 1890, concert in Neue Berliner Musikzeitung 44, no. 6 (6 March 1890): 52. See review of concert under Grieg's direction in the Musical Times and Singing Class Circular, 1 December 1893, 747.

61. Letter from Carreño to Edward MacDowell, 14 February 1890. MacDowell Collection, box 30.

62. Letter from Frances MacDowell to Carreño, 24 June 1892. Teresa Carreño Papers, series 3: Correspondence, folder 8.11.
} 
27 September 1892, they welcomed their first child together, Eugenia. The gossip must have been rampant regarding d'Albert and Carreño's relationship and her pregnancy. Between the fall of 1891 and spring of 1892, several newspapers printed details of d'Albert and Carreño's relationship, implying that the two were already married. Considering that Carreño was pregnant out of wedlock, it is possible that some of the information was fabricated and supplied to the papers by Hermann Wolff (her manager) or by d'Albert and Carreño. ${ }^{63}$

In her letter of 24 June 1892, Fanny MacDowell mentioned Carreño's second husband, Giovanni Tagliapietra, specifically that he was not going on tour in Europe and that he had an eleven-week engagement with bandmaster Patrick Gilmore at Coney Island, New York. She also noted the gossip about Carreño's personal affairs and advised that it would be best for her not to travel with d'Albert to the United States, because she was unsure what Tagliapietra might do if he learned about their relationship.

Following the birth of Eugenia in September, Carreño remained at home for several months, to the aggravation of Hermann Wolff. She finally returned to the stage in January 1893, appearing in countries bordering Germany, including France, Switzerland, and what is now Poland and the Czech Republic. She appeared with d'Albert in several concerts during the next few seasons (through the spring of 1894), performing on two pianos, and debuted his Piano Concerto no. 2, dedicated to her. ${ }^{64}$ During their marriage, Carreño didn't perform works by MacDowell, a decision that was most likely influenced by d'Albert, who disliked MacDowell's music and seemed to have a controlling nature. This choice affected Carreño's relationship with Fanny and Edward MacDowell and is documented in several letters exchanged between them. For example, on 18 September 1896, Fanny MacDowell responded to Carreño that the card she sent Edward MacDowell to congratulate him on his appointment as professor of music at Columbia University had never arrived. In this same letter, she writes, "I hope the day will come when you will feel differently about him and his work-you, who were one of the very first to appreciate \& make known his talent! I do not know what he thinks of your silence when the letters come from every quarter and from some least expected...." ${ }^{55}$ Fanny was also very critical of d'Albert's control over Carreño, especially around child rearing. In a 16 June 1896 letter,

63. For example, see the Chicago Daily Tribune, 9 March 1892, 2, and the San Francisco Call 71, no. 145 (24 April 1892).

64. For example, see the review of the 14 February 1894, concert in Prague, where they performed a Sonata in F Major for two pianos by W. F. Bach. Dalibor 16, no. 17 (3 March 1894): 131.

65. Letter from Frances MacDowell to Carreño, 18 September 1896. Teresa Carreño Papers, series 3: Correspondence, folder 8.11 . 
for example, Fanny wrote: "You will pardon me, my dear, for saying it (but all the same I shall say it!) do you not think you may have been a little unwise a little too extreme-in the new-fangled notions imbibed from that scalawag d'A[lbert]—in the feeding and general management of your little flock?" 66

Around January 1894, Carreño found herself pregnant again, and she took a break from her tedious performance schedule to stay home with her daughter Eugenia. Her daughter Hertha was born on 26 September 1894, and soon thereafter d'Albert deserted Carreño and the children. The next few months must have presented challenges for Carreño, who had to go through another public divorce as well as manage her household, children, and concert schedule. She resumed concert performances in February through May 1895, but they were largely in German cities, and a planned tour to Spain had to be abandoned due to her children's illnesses.

In May 1895, Carreño filed for divorce from d'Albert and moved out of Villa Teresa in Coswig and into a flat at 28 Kürfurstendamm Strasse in Berlin with her youngest children, Eugenia and Hertha, while Teresita and Giovanni continued their education in German boarding schools. The decision to move was most likely due to financial constraints and to be closer to a prominent center of musical activity. On October 3, she was granted a divorce on grounds of willful desertion. ${ }^{67}$

During her years in Coswig and Berlin, she composed her Serenade in E-Flat Minor (1895) and in 1896, her String Quartet in B Minor was published in Leipzig and performed by the Klinger Quartet in the Leipzig Gewandhaus on 29 September 1896. Her activity as a composer, however, decreased greatly over the last two decades of her life while she built her career as a virtuoso performer and maintained an exhausting tour schedule.

As early as 1895, evidenced by a letter written by Fanny MacDowell to Carreño, it seemed that Arturo Tagliapietra, her second husband Giovanni's brother, had become a loyal friend to Carreño and cared deeply for her. Fanny wrote to Carreño that "nothing [Giovanni] Tag[liapietra] could have said would have turned him [Arturo] from his purpose of helping you in any way he could - He is so different from Tag - When I gave him your message his face colored-and he seemed so happy over it as a child." 68 By 1897, Arturo had joined Carreño in Berlin and

\footnotetext{
66. Letter from Frances MacDowell to Carreño, 24 May 1896. Teresa Carreño Papers, series 3: Correspondence, folder 8.11.

67. Details about her divorce from d'Albert were reported in newspapers, including the New York Times, 6 October 1895, 17. See divorce papers in the Teresa Carreño Papers, folder 14.1.

68. Letter from Frances MacDowell to Carreño, 14 June 1895. Teresa Carreño Papers, series 3: Correspondence, folder 8.9.
} 
was keeping a register of her accounts and concert plans, tracking each concert appearance and noting (not always consistently) the details of each concert, such as date, location, type of concert, and amount paid. ${ }^{69}$

During the 1895-96 season, Carreño made appearances in England, Scotland, and other European cities, including some with Hungarian conductor Arthur Nikisch (1855-1922), during which she performed various concertos, including Chopin's First on 12 January 1896 and Beethoven's Fifth on 3 February $1896 .{ }^{70}$ In the fall of 1896 , Carreño appeared in cities across Europe and Russia, including Warsaw on 9 December 1896, where she gave a performance of the Chopin concerto. ${ }^{71}$

\section{RETURN TO THE UNITED STATES (1897)}

After seven years in Europe, she was ready to return to the United States as an internationally acclaimed artist. She sailed from Southampton, England, for New York City on December 24 and arrived on 2 January 1897. By September 1897, her planned US tour had already been widely publicized in American newspapers, such as the Boston Daily Globe, which inserted a curious statement regarding her compositional plans-possibly a reference to the growing interest among composers at that time in composing music based on American folk melodies:

Mme. Teresa Carreno, the famous pianist, who will begin her American tour next January, has been devoting attention to composition of late. Her quartet for string instruments and an intermezzo have met with much success in Germany. Mme. Carreno is now engaged in writing a paraphrase for piano on American negro melodies, including "The New Bully," "I Want Yer, My Honey," "Pickaninny Serenade," "Honey, Meet Me, Do," and "Old Folks at Home."72

Her tour was managed by Rudolph Aronson and included approximately forty concerts across the eastern United States, south through Virginia, as far west as Nebraska, and north into Canada. Plans for an extended tour along the Pacific Coast were dropped, according to R. E. Johnston, her business manager. ${ }^{73}$ The tour began in New York on 8 January 1897 at Carnegie Hall, where she performed Rubinstein's Piano Concerto no. 4 with Hungarian conductor Anton Seidl (1850-

69. Prontuario. Teresa Carreño Papers, series 3: Correspondence, folder 13.3. Cited in Barbara Tilden Thompson, The Twentieth-Century United States Concert Tours of Teresa Carreño (Master's thesis, Temple

University, 2001). Also see "Registro tournée artische di Mme. Teresa Carreño compiute dal 1906-7 al 1916-17," Archivo Histórico de Teresa Carreño, Museo Teresa Carreño.

70. Monthly Musical Record, 1 February 1896, 33-34; Neue Berliner Musikzeitung 50, no. 6 (6 February 1896): 54 .

71. Echo muzyczne i teatralne 13, no. 50 (12 December 1896): 605.

72. Boston Daily Globe, 20 September 1896, 18.

73. Los Angeles Herald, 4 April 1897. 
1898) and the Philharmonic Society Orchestra. According to the music critic for the New York Times, the audience filled Carnegie Hall despite this being a matinee performance. He enthusiastically praised Carreño's performance, writing a well-deserved review that was longer than any that had been published in the United States since her years as a musical prodigy:

Mme. Carreno's performance of the Rubinstein concerto proved that the unbridled enthusiasm of the German press was far from being unmerited. The pianist has advanced to the front rank, where, if yesterday's work was not exceptional, she must claim a commanding position. Her performance revealed a most excellent development of her technic [ sic], which is now far smoother and more certain than it used to be. Her tone is masculine in its breadth and power. Her dynamic range extends from a pianissimo, which is unaffected in that it does not try to be a whisper, to a thundering fortissimo and her palette of color is full of exquisite tints. If her tone yesterday was a trifle hard and short in the cantabile passages, it was because of circumstances beyond her control. Her style is authoritative, dashing, brilliant, yet not without those points of fine repose without which there is no symmetry. Her rhythm is beautiful, and her tempo rubato judicious. She played the big chord passages yesterday with enormous power, while the runs and octaves were treated with beautiful clearness and when necessary with delicious delicacy. Her reading of the work was intensely dramatic. It was less dreamy and restrained in the middle movement than some with which we are familiar, but it was even there strong and thoughtful. The first movement was played with enormous weight, and the stretto was positively exciting. The finale again gave free rein to the pianist's splendid temperament, which is now under the control of a trained will and the direction of a fine intelligence. On the whole, Mme. Carreno gave a notably strong performance of one of the most beautiful compositions for the piano. After several recalls she supplemented it with Chopin's "Berceuse," which she played with crystalline clearness and wooing tone. ${ }^{74}$

In addition to appearances as solo pianist with orchestra, Carreño gave solo recitals, moving beyond the light concert pieces of her youth to the more serious repertoire suited for renowned venues such as the Singakademie in Berlin and Carnegie Hall in New York.

\section{INTERNATIONAL TOURING ARTIST (1897-1917)}

Carreño now wielded power as a seasoned, internationally acclaimed artist. While in Berlin, she wrote to American concert manager R. E. Johnston on 10 June 1897, requesting

Eighty-Concerts, during the season of $1898-1899$. . . I want Five Hundred Dollars per Concert clear of all expenses that is to say, that all and above your percentage, hotels, carriages, railroad expenses and all other travelling expenses for two

74. New York Times, 9 January $1897,5$. 
persons. I want the sum of five hundred dollars for my services-clear of all expenses. These are the principal conditions. As to the piano, as you well know the Steinway piano is what I would like to play, as I think my artistical success would still be greater with it. It would have to be either a Steinway, Chickering or Knabe piano. ${ }^{75}$

Her contract conditions were either not met or Hermann Wolff had other plans for her, because she did not depart for the United States until January 1899 for a tour, which was arranged by Miss Anna Millar (1865-1928), manager of the Theodore Thomas Orchestra.

By June 1897, Carreño had returned to Europe for the 1897-98 season, with performances in cities across Europe and Russia and summer performances in England. She performed Amy Beach's Sonata for Piano and Violin in A Minor, op. 34, with Czech violinist Carl Halir (18591909 ) in 1899. In a letter dated 17 December 1899, Carreño refers to Beach's forthcoming Concerto for Piano and Orchestra, op. 45 (1901), and thanks her for the dedication. Regarding the sonata, she writes:

As you had friends at the Concert here (as you tell me) it is not necessary for me to enter into detailed accounts of how your beautiful Sonata was received by the public, but perhaps, it will please you to know from an experienced old artist as I am, that it really met with a decided success, and this is said to the credit of the public. I think that you would have been pleased with the success and perhaps also, with the interpretation, specially [sic] that of Professor Halir, who played it most beautifully and felt and expressed the greatest admiration for you, as it is only natural he should. We both longed to have had you here with us! ${ }^{76}$

Carreño returned to the United States for a tour from January through May 1899 under the management of J. W. Cochran. During March, she appeared with the Boston Symphony Orchestra in a multicity tour, performing MacDowell's Piano Concerto no. 2 (dedicated to her), Grieg's Piano Concerto, and Tchaikovsky's Piano Concerto no. 1, among other compositions. ${ }^{77}$ Carreño must have written to Edward MacDowell about her performance of his concerto, because she received a letter from him dated 2 March 1899, in which he writes, "I had planned the

\footnotetext{
75. Letter from Carreño to R. E. Johnston, 10 June 1897. Teresa Carreño Papers, series 3 : Correspondence, folder 8.2.

76. Letter from Carreño to Mrs. H. H. A. Beach, 17 December 1899. University of New Hampshire, Special Collections and Archives, Amy Cheney Beach (Mrs. H. H. A. Beach) Papers, 1835-1956, MC 51, box 1 , folder 3 .

77. Here is a selection of reviews of concerts with the Boston Symphony Orchestra: Boston concert on 17-18 March 1899, Boston Daily Globe, 18 March 1899, 5; Baltimore concert on 21 March 1899, "SchlussConzert der Bostoner," Der deutsche Correspondent 59, no. 81 (22 March 1899): 6; New York City concert on 23 March 1899, New York Times, 24 March 1899, 7; Brooklyn concerts on 24 March 1899, "Boston Symphony Concert," Brooklyn Daily Eagle 59, no. 83 (25 March 1899): 5, and on 25 March 1899, "Boston Symphony Concert," Brooklyn Daily Eagle 59, no. 84 (26 March 1899): 4.
} 
whole passage on the broad line of steady development from 'dolce' to 'feroce.' I think the triumph of the few measures in major distracts the steadiness of the progression. Of course I can see how effective the new bit of color would be-and-you shouldn't have asked me!"78

Following her United States tour, she stopped in England to give several concerts at Queen's Hall and St. James's Hall before returning to Berlin for her 1899-1900 concert season with performances across Europe, Russia, and finally England in the spring. During her visit to England, Carreño gave the first English performance of MacDowell's Piano Concerto no. 2 at the Crystal Palace in London on 7 April 1900. The critic for the Musical News wrote:

Madame Carreño gave the first performance in England of an ambitious Concerto for pianoforte and orchestra, in D minor, by Mr. E. A. MacDowell. This gentleman comes from New York; he studied at the Paris Conservatoire, and, later, at the Raff Institute in Frankfort. Judging from the quantity of instrumental and vocal music Mr. MacDowell has written, he would seem to possess the pen of a ready writer, but the example produced on Saturday makes one doubt if this pen is guided by genius. ${ }^{79}$

In October 1900, Carreño set out for a 1900-1901 concert tour across the United States, Canada, Mexico, and Cuba under the management of J. W. Cochran, arriving on November 8 in New York. This same year, Amy Beach dedicated her Piano Concerto to Carreño, but unfortunately, she never had the opportunity to perform this work in a public concert. On 16 November 1900, Carreño performed at Carnegie Hall in the fiftyninth season of the Philharmonic Society as the soloist in Tchaikovsky's Piano Concerto no. 1 under the direction of Austrian conductor Emil Paur (1855-1932). The music critic for the New York Times gave a vivid description of Carreño's performance of the work:

The temptation to compare her reading with that of Gabrilowitsch is powerful. Perhaps, however, no more need be said than this: His was the reading of a thoughtful and poetic young man, seeking the difficile self-control of maturity, and accentuating his nuances in order to make plain the purport of his reading. Hers was the performance of a mature artist, sure of her fame, sure of herself, and not afraid to hurl all delicacy and the hair-spinning of the raffine school to the winds, while she swept the keyboard with the rush of a whirlwind, "set the wild echoes flying" and the whole auditorium throbbing with the magnetic waves of her exuberant temperament. ${ }^{80}$

78. Letter from Edward MacDowell to Carreño, 2 March 1899. Teresa Carreño Papers, series 3 : Correspondence, folder 8.7.

79. Musical News, 14 April 1900, 345.

80. New York Times, 17 November 1900, 6. 
According to the critic for the Sun, Carreño was "applauded until one wondered what change had overtaken the spirit of the usually frigid Philharmonic audience." ${ }^{11}$ In response to the audience's recalls, she performed Chopin's Etude in G-flat Major, op. 25, no. 9 ("Butterfly"). During this tour, she performed in several Mexican cities, including Mexico City, where she appeared at the Teatro del Renacimiento in February performing Tchaikovsky's Piano Concerto no. 1, a concerto she played often during the 1900s. Before heading through the Midwest back to New York (where the tour would end at Carnegie Hall), Carreño performed along the Pacific Coast in California and Washington. In these solo recitals, her repertoire included Mozart's Fantasia in C Minor, K. 475; Beethoven's Piano Sonata no. 18, op. 31, no. 3, and Piano Sonata no. 14, op. 27, no. 2; Chopin's Nocturne, op. 27, no. 2, Etude, op. 10, no. 5, Polonaise in A-flat Major, op. 53, Prelude, op. 28, no. 15, Prelude, op. 28, no. 22, Etude, op. 25, no. 1, and Ballade in A-flat Major, op. 47; Schubert's Vier Impromptus, D. 935, no. 2, and Marche militaire, D. 733, no. 1; Liszt's "La campanella" from the Grandes études de Paganini, S. 141, Soirées de Vienne, S. 427, and a Sonnetto del Petrarca from Années de pèlerinage, deuxième annèe, S. 161; Tchaikovsky's Nocturne; Regina Watson's Scherzino from An Arabian Night; and her own Kleiner Walzer, which she often performed as an encore. She ended this tour in New York, and some newspapers reported that this was her final tour before retirement. The critic for the Los Angeles Times wrote, "Teresa Carreño, the popular pianist, gave a farewell recital at Carnegie Hall on 22 April 1901, which completed her final tour of America, after many years concerting in this country, where her name has become a household word. Her retirement will leave a void that, for many reasons, will be almost impossible to fill, and a keen regret will be felt among the thousands of her admirers in North America." 82 Fortunately for the music lovers in the United States, Carreño would return for the 1907-8 and 1909-10 concert seasons, and then for a final time in 1916, before her death in 1917.

After 1897, once Carreño had completed a tour across North America, she made a tradition of stopping over in England to appear in a few concerts before heading to her summer residence, where she would spend time with her family and recuperate, practice, and give music lessons. At the end of the summer of 1901, she returned to Berlin ready for the 1901-2 concert season, which would take her across Europe and England. While on tour in Germany and Poland, Carreño received a letter from Fanny MacDowell, dated 19 November 1901, reporting that her

81. Sun, 17 November $1900,4$.

82. Los Angeles Times, 5 May 1901, B2. 
manager, Hermann Wolff, had become ill. He eventually died, sometime before 3 February 1902. It must have been a great loss for her. Wolff had managed her career for the last twelve years (since her Berlin debut) and helped her rise to international acclaim, but he had also become a good friend. Carreño finished her 1901-2 tour, returning to Berlin in May, and going forward, Hermann's wife Louise, who was also a close friend of Carreño's, managed the Hermann Wolff Concert-Direction agency until her death in 1935.

In August 1901, Fanny MacDowell again wrote to Carreño about Arturo Tagliapietra, commenting on his assistance with Teresita over the last year and asking about personal matters between Arturo and his exwife. ${ }^{83}$ As always, Fanny shared her advice with Carreño, whether wanted or not, and on 24 September 1901, she wrote to her about the possibility of marrying Arturo.

I had hoped you would continue to the end of your life entirely your own mistress of your life as you are entire mistress of your piano - Having made three ventures in matrimony and having lived down all the adverse comments, sneers and ridicule of having separated from all 3-and they all living - and to the world seemingly happily married. I hoped and prayed you would lead your own life-and be happy in your art-with all your leisure time spent in the bringing up of your children to whom you are such a loving devoted mother! Frankly, I am sorry that you could not content yourself with this life which you have led since you separated from that beastly d'Albert-I am sorry for the misjudgment that will be pronounced-publicly and privately of your marrying a 4th time!-It seems incredible!-and even you cannot wonder that people will talk! The press will sneer-and only a few friends will stand by with ready defence of you. ${ }^{84}$

Although Fanny was critical of Carreño's decision to marry for a fourth time, she ultimately supported Carreño's choice, and in the same letter wrote, "Since you have both decided otherwise I accept it-giving you both the prayers and best wishes of my heart for your happiness." 85 Fanny was one of Carreño's closest friends and had supported Carreño through each of her failed marriages and the other challenges she experienced throughout her life. She cared deeply about Carreño's wellbeing as well as her public persona and felt it her duty to warn Carreño or provide her with a critical assessment. In June 1902, Carreño married Arturo. Unlike her previous marriages, their marriage appeared to be joyful and ended only with her death in 1917.

83. Letter from Frances MacDowell to Carreño, 16 August 1901. Teresa Carreño Papers, series 3: Correspondence, folder 8.8 .

84. Letter from Frances MacDowell to Carreño, 24 September 1901. Teresa Carreño Papers, series 3 : Correspondence, folder 8.9.

85. Ibid. 
The next five seasons, between 1902 and 1907, consisted of nonstop touring across Europe, England, and Scotland. On 22 April 1902, Carreño had the pleasure of performing Grieg's Piano Concerto in Warsaw under Grieg's direction. She was fond of Grieg's compositions, having performed his concerto and miniature piano works since the early $1880 \mathrm{~s} .{ }^{86}$ The composer and Carreño exchanged several letters discussing additional repertoire for this concert, and although Grieg had originally suggested his Ballade, Carreño chose to substitute it with To elegiske melodier and Folkelivsbilleder, which included "Fjeldslåt" (In the Mountains), "Brudefølget drager forbi" (Bridal Procession), and "Fra karnevalet" (From the Carnival). ${ }^{87}$

Around 1903, advertisements for the Metrostyle Pianola (priced at $\$ 300$ ) featuring Carreño, along with a number of artists who interpreted music for the pianola, began to appear in the New York Times. ${ }^{88}$ Between 1905 and 1908, Carreño recorded approximately forty-six compositions on the player piano by composers including Beethoven, Carreño, Chopin, Liszt, MacDowell, Rubinstein, Schumann, and Tchaikovsky. Most of these were produced by Welte-Mignon and then reissued by other manufacturers, such as Ampico, Duca, and Recordo. Piano-roll recordings were not always of the best quality and occasionally required corrections. Carreño was unhappy with a recording in 1907 by WelteMignon and, with her professional reputation to consider, on 6 February 1908, she wrote to the editors of the Seattle Times and the Seattle Post Intelligencer informing them that she had asked that Welte not use the piano rolls recorded in 1907 because the corrections had not been completed. Since they had released them despite her request, she asked the newspaper editors to print her letter to inform the public. ${ }^{89}$

In 1907, Carreño set off for her first tour of Australia and New Zealand with Arturo and her daughters Hertha and Eugenia. They arrived in Fremantle on 8 May 1907, before she began her tour in Melbourne, and continued across Australia, Tazmania, and New Zealand for approximately 107 concerts between May 1907 and October 1907.90 This tour was under the direction of Benno Scherek, who also accompanied Carreño on a second piano for performances of concertos. The Australian public had long awaited the opportunity to hear Teresa

86. Further discussion of Carreño's performances of works by Grieg can be found in Anna Kijas, "A Suitable Soloist for My Piano Concerto: Teresa Carreño as a Promoter of Edvard Grieg's Music," Notes 70, no. 1 (September 2013): 37-58.

87. Letters from Edvard Grieg to Carreño, 1 and 10 April 1902. Teresa Carreño Papers, series 3: Correspondence, folder 8.5. Letter from Carreño to Edvard Grieg, 8 April 1902. Bergen Offentlige Bibliotek, Nr. 0214307.

88. New York Times, 15 October 1903, 6.

89. Letter from Carreño, 6 February 1908. Carreño Papers, series 3: Correspondence, folder 9.12.

90. Announcements of Carreño's tour appearances appeared a few months in advance, such as the one in the Sydney Morning Herald, 12 April 1907, 7. 
Carreño perform. Her first concert, on 18 May 1907, was held at the Town Hall in Melbourne. The critic for the Advertiser wrote that there was a "tremendous crowd that desired admittance." She performed Beethoven's Piano Concerto no. 5 and Liszt's Fantaisie hongroise no. 14, with the Marshall Hall Orchestra. ${ }^{91}$ Following the appearance in Melbourne, she performed at the Sydney Town Hall on 7 June 1907, where the critic for the Sydney Morning Herald reported that

In the slowly lengthening record of the Sydney Amateur Orchestral Society no occasion has been invested with the mingled lustre and charm that attended its association with Mme. Teresa Carreno last night. ... This worldfamous artist has been talked of in musical circles here for long years, and so much has been made of her physical powers that many people anticipated an august type of "piano-smasher." On the contrary, the actual revelation was of an artist of consummate taste and delicacy. The audience heard her first in her most classic mood, in which, however, there was much tenderness, and yet later, in a favourite Liszt fantasia, in which there is some excuse for effects ad captandum vulgus, the overwhelming brilliancy of the player was wholly without alloy. ${ }^{92}$

The critic then described Carreño's performance of Beethoven's Piano Concerto no. 5:

Mme. Carreno gave an indisputably great interpretation of her part. Its chief characteristic consisted in a soft deliberation of touch, a leisurely perfection, which belongs only to the most accomplished technique backed by a definite purpose.... Throughout the movement, and indeed the whole work, Mme. Carreno appeared to refrain from the brilliancy in tone by which she was so lavish later in the evening, evidently subduing her method to her conception of the master's music. The effect of playing of this nature in the Adagio, with its accompaniment for muted strings, is not to be described in words. ${ }^{93}$

In addition to the Beethoven concerto, she performed Liszt's Fantaisie hongroise no. 14, and as an encore, Schubert's Marche militaire, D. 733, no. 1 (arr. Tausig).

During this tour, the family had cause for celebration when Carreño's daughter Teresita was married on June 5 to Col. Eustace Blois in Melbourne. Following her final concerts in August at the Choral Hall in Auckland, New Zealand, Carreño and her family traveled to Fiji before returning to the United States for the 1907-8 concert season under the management of the John Church Company. Carreño arrived in Vancouver, British Columbia, and made her way to Chicago for her first concert on 24 November 1907.

91. Advertiser [Adelaide, South Australia], 20 May 1907, 8.

92. Sydney Morning Herald, 8 June 1907, 14.

93. Ibid. 
Unfortunately, Carreño would suffer a huge loss during this tour. Her friend Edward MacDowell died on 23 January 1908 from an illness that had started troubling him around 1904. ${ }^{94}$ In 1907, Edward's wife Marian had written several letters to Carreño discussing his decline and mentioning that although he no longer seemed to recognize Marian, his face always brightened when she mentioned Carreño's name. ${ }^{95}$ Unable to contact Carreño via telegram, Fanny MacDowell wrote her a letter that Edward had died at $8 \mathrm{pm}$ on the evening of January $23 .{ }^{96}$ Carreño, still on tour, sent Marian a letter from her hotel room in Denver expressing her condolences and also sharing in the grief. She wrote, "The last great blow has befallen you, my dearest child, and here you stand facing the worst, the cruelest fate that could be yours in life losing the dearest and best of husbands! The world loses one of its greatest genius our art loses one of its brightest lights and you my poor Marion [sic], lose all we all lose and still more than we, for you lose the loving the dear companion of your life!"97 Carreño had concerts scheduled for the next two months, so it was mid-March 1908 before she could meet with Fanny and Thomas MacDowell and share in the grief of losing Edward. Throughout Fanny's and Carreño's written exchanges, they often referred to illnesses and health issues, but in a letter written on 13 March 1908, Fanny specifically mentioned Carreño's eye trouble and recommended that she use boracic acid as an eye rinse. ${ }^{98}$ Several weeks before wrapping up her concert season, Carreño participated with several other artists-including baritone David Bispham, singer Corinne Rider-Kelsey, and cellist May Mukle-in the MacDowell Memorial Concert on 31 March 1908 at Carnegie Hall, performing his Étude de concert, op. 36, and Piano Concerto no. 2 with the Philharmonic Orchestra under direction of Russian conductor Vasily Safonov (1852-1918). ${ }^{99}$

In 1908, while touring the Pacific Northwest, Carreño and Arturo Tagliapietra purchased lot \#130 in Grossmont, California (a suburb of San Diego) from Col. Ed Fletcher, probably in anticipation of retiring there one day. This was a real estate development that was marketed as an artist's colony, and an advertisement (fig. 8) featured the names of

\footnotetext{
94. For details about his illness and decline, see item Bomberger, 267-83.

95. Letters from Marian MacDowell to Carreño, 17 November and 19 December 1907. Teresa Carreño Papers, series 3: Correspondence, folder 8.13.

96. Letter from Frances MacDowell to Carreño, 23 January 1908. Teresa Carreño Papers, series 3 : Correspondence, folder 8.10.

97. Letter from Carreño to Marian MacDowell, 25 January 1908. MacDowell Collection, box 43. Throughout this passage, I have corrected Carreño's misspelling of "lose" as "loose."

98. Letter from Frances MacDowell to Carreño, 13 March 1908. Teresa Carreño Papers, series 3: Correspondence, folder 8.8.

99. New York Times, 1 April 1908, 7. "Noted Artists in MacDowell Concert," Musical America, 4 April $1908,17$.
} 


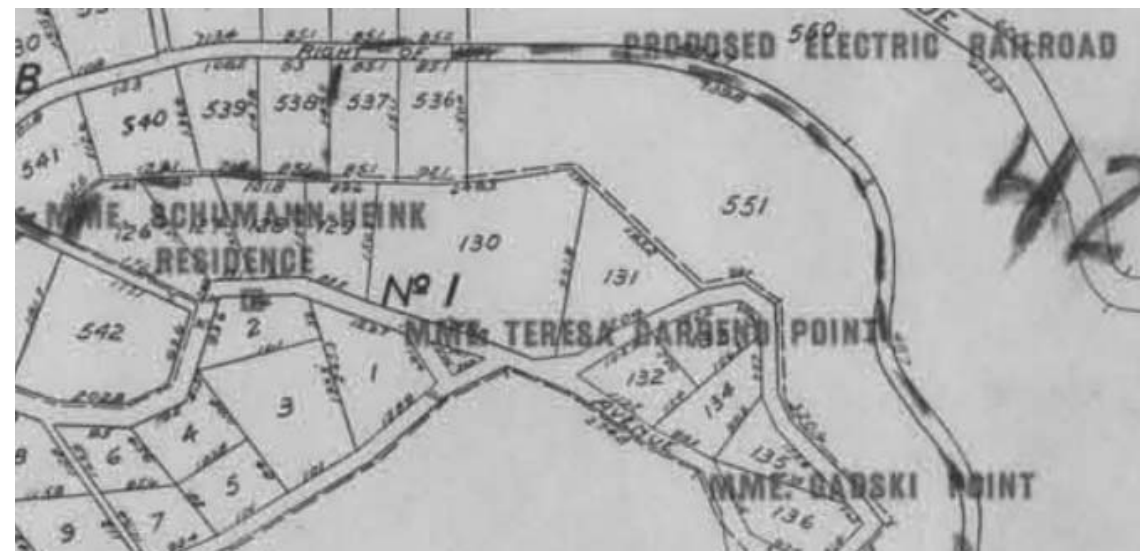

Fig. 8. Detail from map of Grossmont, California, showing Carreño's plot, no. 130, labeled "Mme. Teresa Carreno Point” (Special Collections \& Archives Online Maps, G4364 .G76 1923, University of California San Diego Library) http:/ / roger.ucsd.edu/record=b4516003 S9

landowners, including Carreño and several famous opera singers, such as Lilli Lehmann, Ernestine Schumann-Heink (1861-1936), and Johanna Gadski (1872-1932).

Following her concert tour, Carreño departed for a short trip to Italy with her husband, daughters, Thomas MacDowell, Fanny MacDowell, and their friend Juan Buitrago before returning to England and setting off on a 1908-9 concert tour across Europe, England, Scotland, and Ireland. Carreño returned to the United States again for the 1909-10 concert season, under the management of the John Church Company and endorsed by the Everett Piano Company. This concert tour would take her from New York to Hawaii, from where she would immediately sail for her 1910-11 tour of Australia, New Zealand, and South Africa. Unfortunately, Fanny MacDowell died on 6 October 1909, before Carreño had arrived in the United States. Carreño must have been heart broken, especially after having experienced the great loss of Edward MacDowell the previous year. With what must have been a heavy heart, she performed her first concert of the season on 3 November 1909, in Brooklyn, New York. ${ }^{100}$ Her tour overlapped with the New York residency of Austrian composer and conductor Gustav Mahler (1860-1911), who conducted performances of the Metropolitan Opera, the New York Symphony Orchestra, and the New York Philharmonic. On 25 and 26 November 1909, Carreño performed Weber's Konzertstück in F minor for 
piano and orchestra, op. 79, with the New York Philharmonic under Mahler. ${ }^{101}$ During this tour, she also gave three classes at the American Institute of Applied Music in New York City. ${ }^{102}$

Following her second tour (1910-11) of Australia and New Zealand, and several performances in South Africa, Carreño took several months off before beginning her 1911-12 concert tour in Berlin, which was followed by performances in England, Scotland, Ireland, and cities across Europe and Russia. During the fall of 1911, she performed with cellist Mischa Elman in several concerts in England and Ireland. In Liverpool, Carreño performed MacDowell's Piano Concerto no. 2 on 21 November 1911, for what the critic believed was the first time. ${ }^{103}$ The year 1912 marked Carreño's fiftieth anniversary as a performer, and a golden anniversary celebration was held on 21 November 1912, organized by a committee including German composer Richard Strauss (1864-1949), Hungarian soprano Etelka Gerster (1855-1920), and Lilli Lehmann. ${ }^{104}$

In the summer of 1913, Carreño's son Giovanni was planning to visit her in Obersalzberg, Germany. In preparation for the visit, they exchanged several letters, which included a discussion of his sister Teresita, whom Carreño regularly complained about due to her reckless behavior and continual requests for financial assistance. Her constant troubles with Teresita are also documented in letters to Fanny MacDowell. Before Giovanni's visit in 1913, in a letter dated 21 May 1913, Carreño wrote about Teresita's recent requests for money to purchase clothing and her own exasperation with her daughter, who was not a good role model for her younger children:

A few weeks ago I paid about five hundred Lire to the hospital for her illness. To say the plain truth, Teresita has exhausted all my patience with her behavior and I am tired out and want her to leave me alone. She has brought me nothing but sorrow and anxiety all her life and has cost me a small fortune which I have had to work and slave for. The consequence is that I am not willing to sacrifice anything more for a daughter who through her selfishness and caprices has brought so much suffering upon me and who only remembers my existence when she is in trouble and needs my help. ${ }^{105}$

She ends her letter by telling Giovanni that Teresita is not welcome to spend the summer with her, because she needs to consider her own health as "it is necessary for you all that I can keep on working and Teresita would make me so ill that I would be totally unfit for my next

101. H. F. P., "Carreno with the Philharmonic," Musical America, 4 December 1909, 25.

102. "Carreno Holds Classes at a New York School," Musical America, 23 April 1910, 29.

103. Musical Standard, 2 December 1911, 358-59.

104. New York Times, 15 December 1912, C4.

105. Letter from Carreño to Giovanni Tagliapietra (son), 21 May 1913. Teresa Carreño Papers, series

3: Correspondence, folder 8.2. 
winter's work or to give the many lessons which I shall have to give in Salzberg $[s i c]$ in order to be able to pay the expenses of our living there."106

On 30 July 1913, Carreño lost yet another close friend and mentor, Regina ("Ginka") Watson. Only a few months earlier, on January 5, Carreño had written to Ginka about the jubilee held in her honor in Berlin. In this letter, Carreño expressed her deep gratitude to Ginka for helping her become the artist she was and for her support.

Do you realize that as an artist I am your creation? Do you know how necessary you are to me as an artist! You, my darling Beloved, have brought to be what the world says I am. Through you I have had the courage to work and go on living, at times when I was in despair and did not care to live any longer. Not even the thought of my children gave me the energy which the thought of giving you a sorrow brought to one and made me go on living, go on in my profession. Do you know what would happen to me if you left me? Have you ever given this possibility a thought my darling? Well darling, the artist in me, would die with you. All my ambition of keeping myself, keeping alive my better self, which is my artistic self would disappear from the moment that I cannot have you as my guiding star, as my good angel in life. What ever I have accomplished, has been for your sake more than for mine, and without you my better self does not, cannot exist. ${ }^{107}$

Carreño may not have seen Ginka before her death, but the letter she wrote her was truly a tribute to their friendship and the mentorship she had provided Carreño. It illustrates some of the low points in Carreño's life and her strong reliance on her closest female friends, such as Ginka and Fanny MacDowell.

On her way to the United States for a 1913-14 tour (see fig. 9), which would include stops in Canada, Carreño gave several concerts in England and Scotland in October. This tour was managed by the Wolfsohn Musical Bureau and underwritten by the Everett Piano Company. She was scheduled for approximately sixty concerts, including appearances with the Boston Symphony Orchestra and the New York Philharmonic Society. Her first concert took place on 30 October 1913 at Carnegie Hall, where she performed one of her favorites, Tchaikovsky's Piano Concerto no. 1, under conductor Josef Stransky. Overall, she received enthusiastic approval, but music critics mentioned the lack of orchestral support in the first movement when Carreño increased or decreased her tempo. ${ }^{108}$ Carreño returned to Berlin following her final

\footnotetext{
106. Ibid
}

107. Letter from Carreño to Regina Watson, 5 January 1913. Library of Congress, Manuscript Division, Regina Watson Memory Book, 1869-1913, MacDowell Colony Records, MSS55012, box OV 1, container 74.

108. See review in the New York Times, 31 October 1913, 11, and H. F. P., "Carreño Heard with the Philharmonic," Musical America, 8 November 1913, 22. 


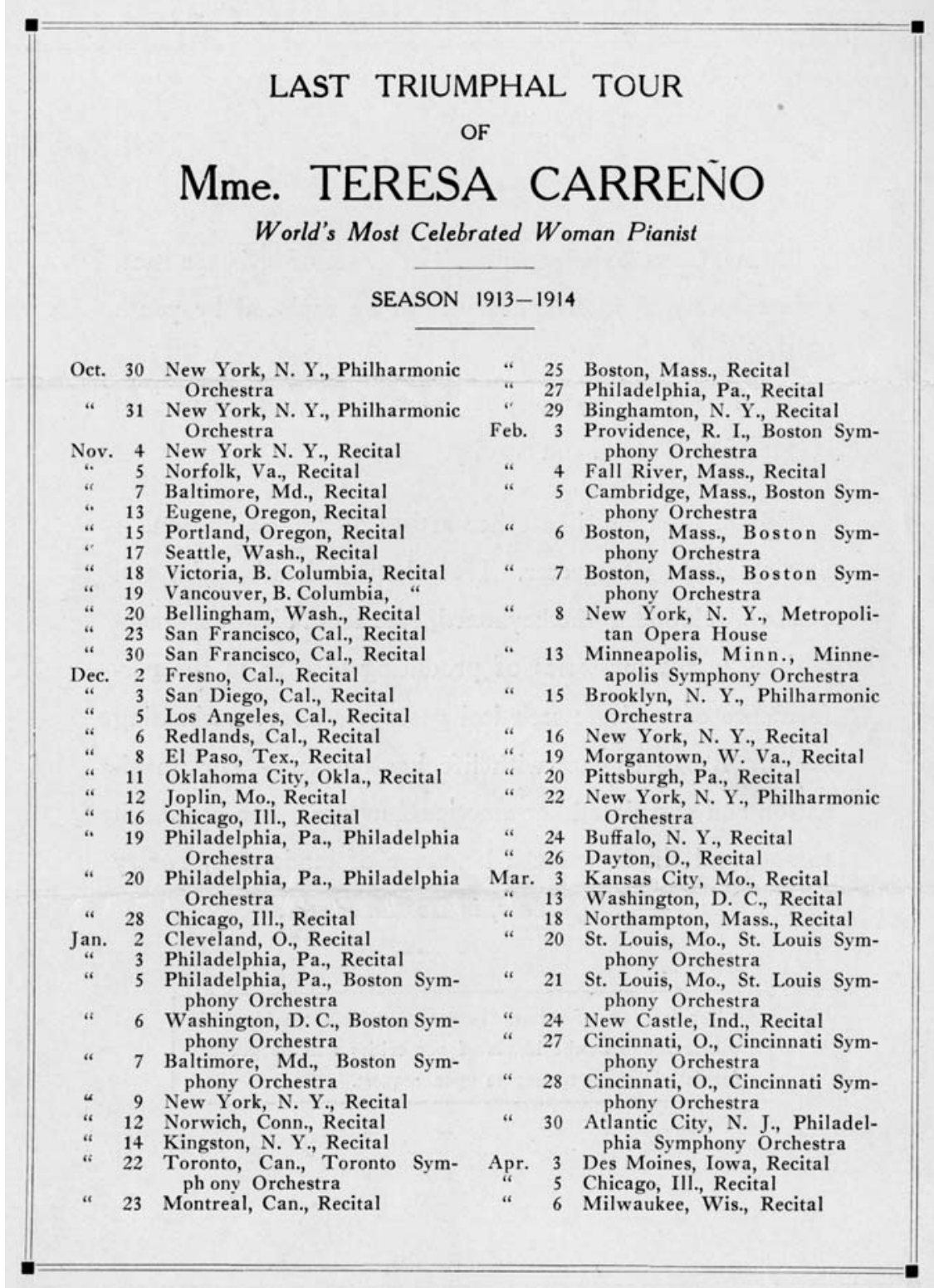

Fig. 9. Performance listings for the 1913-14 season (Teresa Carreño Papers, folder 14.8: Concert Programs) 
concert at Jordan Hall in Boston, only a few months before the outbreak of World War I in July 1914. ${ }^{109}$

Although Carreño continued to perform in Europe during 1914-16, the number of opportunities began to decrease, and she and her family were presented with a number of challenges. Her students stopped traveling during the summer months to study with Carreño, her assets were frozen, and two of her children, Giovanni and Teresita, were arrested separately under suspicion of being German spies. ${ }^{110}$ Carreño had to negotiate with authorities for the release of her children. In 1915, Carreño decided she would return to the United States in September 1916 for a tour with J. W. Cochran. She relinquished her apartment on Kurfürstendamm Strasse in Berlin and moved into the Della Robbia apartments at 740 West End Avenue in New York City. During the 1916-17 season, Carreño performed in approximately twenty-three concerts beginning in Boston and extending west as far as North Dakota before returning to the northeast and heading south to Florida. She performed in St. Petersburg before sailing on the Olivette with Arturo for a short concert series in Havana, Cuba, in March 1917. A concert that may have held special meaning for Carreño took place on 12 December 1916 at the high school auditorium in New Rochelle, New York. This was the city in which she resided during the 1870s and 1880s and where her daughter Lulu was buried. It was a Young People's Subscription Concert, and the proceeds were donated to the New Rochelle Day Nurseries. She performed Beethoven's Piano Sonata no. 23, op. 57; Chopin's Prelude, op. 28, no. 15, Nocturne, op. 37, no. 2, Etude, op. 10, no. 5, Polonaise in A-flat Major, op. 53, and Waltz, op. 64, no. 2; Schumann's Études symphoniques; Liszt's Liebesträume, S. 541; Schubert's Marche militaire, D. 733, no. 1 (arr. Tausig); her own Kleiner Walzer, and Liszt's Rhapsodie hongroise no. 6, S. $244 / 6 .^{111}$

In anticipation of staying in the United States, Carreño accepted a teaching position at the Chicago Musical College that would begin in the summer of 1917; however, she did not get the opportunity to teach that summer. ${ }^{112}$ During her trip to Havana, Carreño was faced with health issues, which forced her to cancel three of her four concerts and return to New York, where she was diagnosed with diplopia. Before leaving Havana, she managed to give one performance at the Sala Espadero on 18 March 1917, where she performed Beethoven's Piano Sonata no. 23,

109. Boston Daily Globe, 16 April 1914, 17.

110. Accounts of their arrests appeared in "Echoes of Music Abroad," Musical America, 4 September 1915, 13, and "Carreño's Son Accused," Musical America, 25 September 1915, 3.

111. New Rochelle Pioneer 58, no. 36 (16 December 1916): 2.

112. Musical America 25, no. 25 (21 April 1917): 16. 


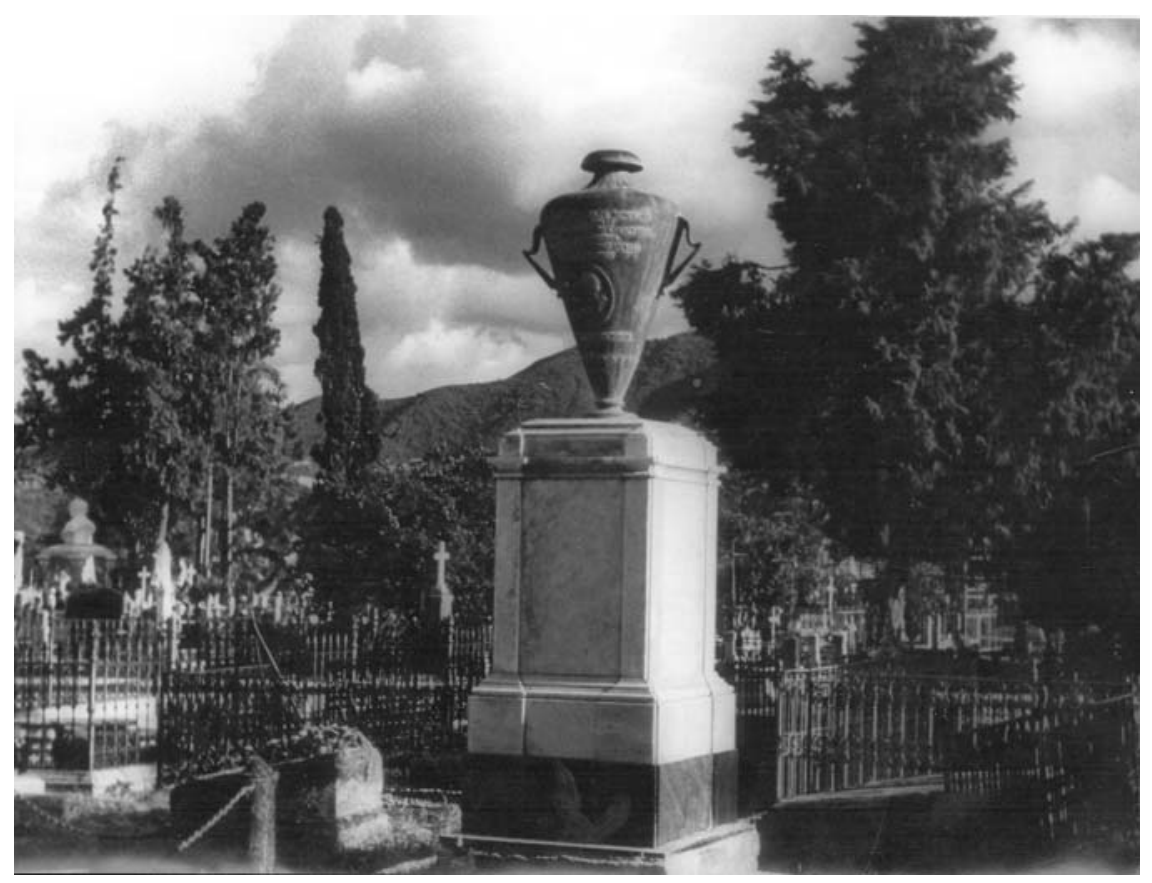

Fig. 10. Grave site of Teresa Carreño in Caracas, Venezuela (Teresa Carreño \& Eugen d'Albert Gesellschaft zu Coswig Persönliche Dokumente, Fotografien Ifd. Nr. 16, O-8190029)

op. 57; Chopin's Prelude, op. 28, no. 15, Nocturne, op. 37, no. 2, and Polonaise in A-Flat Major, op. 53; Schumann's Études symphoniques; and Liszt's Liebesträume and Rhapsodie hongroise no. 6. According to a daily planner that she kept during this time, Carreño continued to give occasional lessons, but she must have sensed that she did not have much time remaining, and in May, she filed her will at the Surrogates' Court in New York. ${ }^{113}$ On June 12, Teresa Carreño died in her apartment, and her body was cremated after her funeral on 14 June 1917. Her husband, Arturo Tagliapietra, sold the Grossmont, California, land back to Col. Ed Fletcher for a sum of $\$ 2,000$ (with 6 percent interest over two years) in 1927. By 1931, Marta Milinowski had gained access to Carreño's materials (later to be purchased by Vassar College) and was beginning to write her biography. In 1934, Arturo held an estate sale of Carreño's furniture and belongings at the Wise Auction Company. ${ }^{114}$ In 1938, her ashes were

113. Appointment book. Teresa Carreño Papers, folder 13.2.

114. New York Times, 2 May 1934, L17. 
repatriated to Venezuela; they were later exhumed and interred on 9 December 1977 at the Panteón Nacional (fig. 10).

\section{ABSTRACT}

This biography of Teresa Carreño (1853-1917) is excerpted from the forthcoming book, The Life and Music of Teresa Carreño (1853-1917): A Guide to Research (A-R Editions), which is a survey of extant primary sources, criticism, compositions, and recordings from Carreño's career. The aim of this biography and forthcoming book is to examine, or in many cases re-examine, the primary and secondary sources that can provide a deeper historical context to Carreño's legacy as a composer and pianist, and bring greater visibility to her musical contributions. Correspondence, newspaper articles or reviews, legal documents, and other sources were closely examined and provide details that may have been overlooked or excluded from earlier biographical writings about Carreño. The biography provides an overview of Carreño's career from musical prodigy — composing and performing by the age of eight—to an internationally acclaimed artist in the 1910s. Important personal and professional relationships that impacted her deeply, such as those with Frances MacDowell and Regina Watson, are discussed. Her concert repertoire selections and details about performances over the course of her career are selectively examined in order to shed light on performance and reception practices during this period. Woven into the narrative are important moments from Carreño's life that demonstrate the challenges and choices she had to make as a professional musician who was also a mother, wife, and friend.

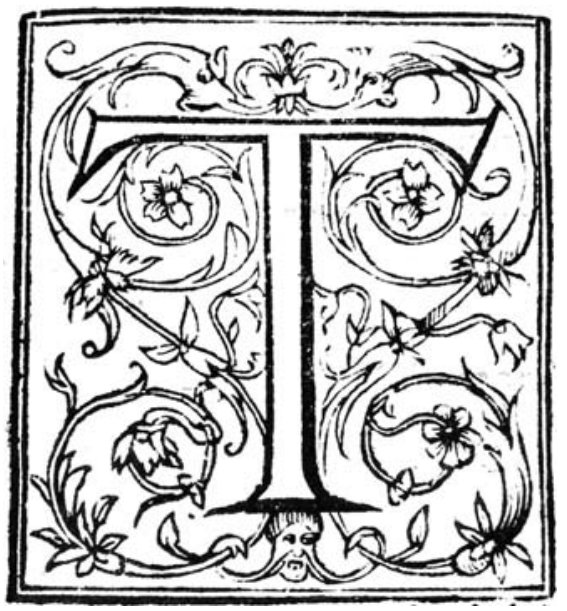

